\title{
16. PLEISTOCENE VOLCANIC ROCKS IN THE MARIANA FOREARC REVEALED BY DRILLING AT SITE 781 ${ }^{1}$
}

\author{
Michael S. Marlow, ${ }^{2}$ Lynn E. Johnson, ${ }^{3}$ Julian A. Pearce, ${ }^{4}$ Patricia B. Fryer, ${ }^{3}$ Ledabeth G. Pickthorn, ${ }^{2}$ \\ and Bramley J. Murton ${ }^{5}$
}

\begin{abstract}
Geophysical surveys of the Mariana forearc, in an area equidistant from the Mariana Trench and the active Mariana Island Arc, revealed a 40-m-deep graben about $13 \mathrm{~km}$ northwest of Conical Seamount, a serpentine mud volcano. The graben and its bounding horst blocks are part of a fault zone that strikes northwest-southeast beneath Conical Seamount. One horst block was drilled during Leg 125 of the Ocean Drilling Program (Site 781).

Three lithologic units were recovered at Site 781: an upper sedimentary unit, a middle basalt unit, and a lower sedimentary unit. The upper unit, between 0 and 72 mbsf, consists of upper Pliocene to Holocene diatomaceous and radiolarian-bearing silty clay that grades down into vitric silty clay and vitric clayey silt. The middle unit is a Pleistocene vesicular, porphyritic basalt, the top of which corresponds to a high-amplitude reflection on the reflection profiles. The lower unit is a middle to upper (and possibly some lower) Pliocene vitric silty clay and vitric clayey silt similar to the lower part of the upper unit. The thickness of the basalt unit can only be estimated to be between 13 and $25 \mathrm{~m}$ because of poor core recovery ( $28 \%$ to $55 \%$ ). The absence of internal flow structures and the presence of an upper glassy chilled zone and a lower, fine-grained margin suggest that the basalt unit is either a single lava flow or a near-surface sill. The basalt consists of plagioclase phenocrysts with subordinate augite and olivine phenocrysts and of plagioclase-augite-olivine glomerocrysts in a groundmass of plagioclase, augite, olivine, and glass. The basalt is an island arc tholeiite enriched in large-ion-lithophile elements relative to high-field-strength elements, similar to the submarine lavas of the southern arc seamounts. In contrast, volcanic rocks from the active volcanoes on Pagan and Agrigan islands, $100 \mathrm{~km}$ to the west of the drill site, are calc-alkaline.

The basalt layer, the youngest in-situ igneous layer reported from the lzu-Bonin and Mariana forearcs, is enigmatic because of its location more than $100 \mathrm{~km}$ from the active volcanic arc. The sediment layers above and below the basalt unit are late Pliocene in age (about $2.5 \mathrm{Ma}$ ) and normally magnetized. The basalt has schlierenlike structures, reverse magnetization, and a $\mathrm{K}-\mathrm{Ar}$ age of $1.68 \pm 0.37 \mathrm{Ma}$. Thus, the basalt layer is probably a sill fed by magma intruded along a fault zone bounding the horst and graben in the forearc. The geochemistry of the basalt is consistent with a magma source similar to that of the active island arc and from a mantle source above the subducting Pacific plate.
\end{abstract}

\section{INTRODUCTION}

\section{Volcano-Tectonic Setting}

Subduction of the Pacific plate beneath the Philippine Sea plate began by the middle Eocene and formed the proto-Mariana arc system (Uyeda and Ben-Avraham, 1972; Hilde et al., 1977; Ogawa and Naka, 1984; Karig, 1975). Seafloor spreading, between about 30 and $17 \mathrm{Ma}$, formed the Parece Vela Basin and isolated the Palau-Kyushu Ridge, now a remnant arc, from its magma source. The West Mariana Ridge, also a remnant arc, formed to the east from 20 to $9 \mathrm{Ma}$ and was isolated when spreading began in the Mariana backarc basin (or Mariana Trough; Hussong and Fryer, 1982). The modern Mariana Island Arc has been active since 5 to 6 Ma coincident with the opening of the Mariana backarc basin (Fig. 1; Karig, 1971; Hussong and Uyeda, $1982 \mathrm{~b})$. The fundamental problems concerning the origin of the forearc basement remain unsolved, despite extensive studies of the Mariana forearc by Karig (1971), Hussong and Uyeda (1982b), Hussong and Fryer (1982, 1985), Mattey et al. (1980), Meijer et al.

\footnotetext{
'Fryer, P., Pearce, J. A., Stokking, L. B., et al,, 1992. Proc. ODP, Sci, Results, 125 College Station, TX (Ocean Drilling Program).

2 U.S. Geological Survey, 345 Middlefield Road, Menlo Park, CA 94025, U.S.A (Present address: Naval Research Laboratory, Code 5110, Washington, DC 20375-5000, U.S.A.)

${ }^{3}$ School of Ocean and Earth Science and Technology, University of Hawaii, 2525 Correa Road, Honolulu, HI 96822, U.S.A.

${ }^{4}$ Department of Geological Sciences, Durham University, South Road, Durham DHI 3LE, United Kingdom.

${ }^{5}$ Institute of Oceanographic Sciences, Wormley, Surrey GU8 5UB, United Kingdom.
}

(1982), Mrozowski et al. (1982), Wood et al. (1982), Bloomer (1983), Karig and Ranken (1983), Ogawa and Naka (1984), Fryer et al. (1985, 1987), Hussong and Fryer (1985), Bloomer and Hawkins (1983, 1987), Fryer and Fryer (1987), and Johnson and Fryer (1990). Of the three suggested models for basement origin-i.e., entrapment of oceanic lithosphere (Hilde and Uyeda, 1983; Mattey et al., 1980), sediment and Pacific plate accretion (or obduction) (Hussong and Uyeda, 1982a), or arc volcanism (Hussong and Uyeda, 1982b) - only arc (supra-subduction zone) volcanism satisfies the previously available seismic, petrologic, and geochemical data. The recent discovery of Cretaceous mid-ocean ridge basalt (MORB), ocean island basalt (OIB), and radiolarian chert about $50 \mathrm{~km}$ west of the trench slope break at the latitude of Ocean Drilling Program (ODP) Site 781 requires reevaluation of this conclusion (Johnson and Fryer, 1990; Johnson et al., in press). If the forearc is composed solely of subduction-related material, a significant amount (at least $50 \mathrm{~km}$ ) of erosion of the forearc is necessary to explain the presence of arc volcanics exposed in the inner trench wall (Bloomer, 1983; Bloomer and Hawkins, 1983). However, the presence of a small quantity of OIB in the inner trench wall and MORB in the outer forearc, coupled with seismic and bathymetric data from the southern part of the forearc, suggests some post-Oligocene accretion (Bloomer, 1983; Karig and Ranken, 1983; Johnson and Fryer, 1990), or the OIB and MORB in the forearc could be engulfed by later arc magmas.

The region around Site 781 from $18^{\circ}$ to $219 \mathrm{~N}$ is tectonically active and characterized by vertical faulting between blocks in the forearc (Mrozowski et al., 1982; Marlow et al., 1990). For instance, a large, uplifted plateau is on strike with the northeast-trending fault that 


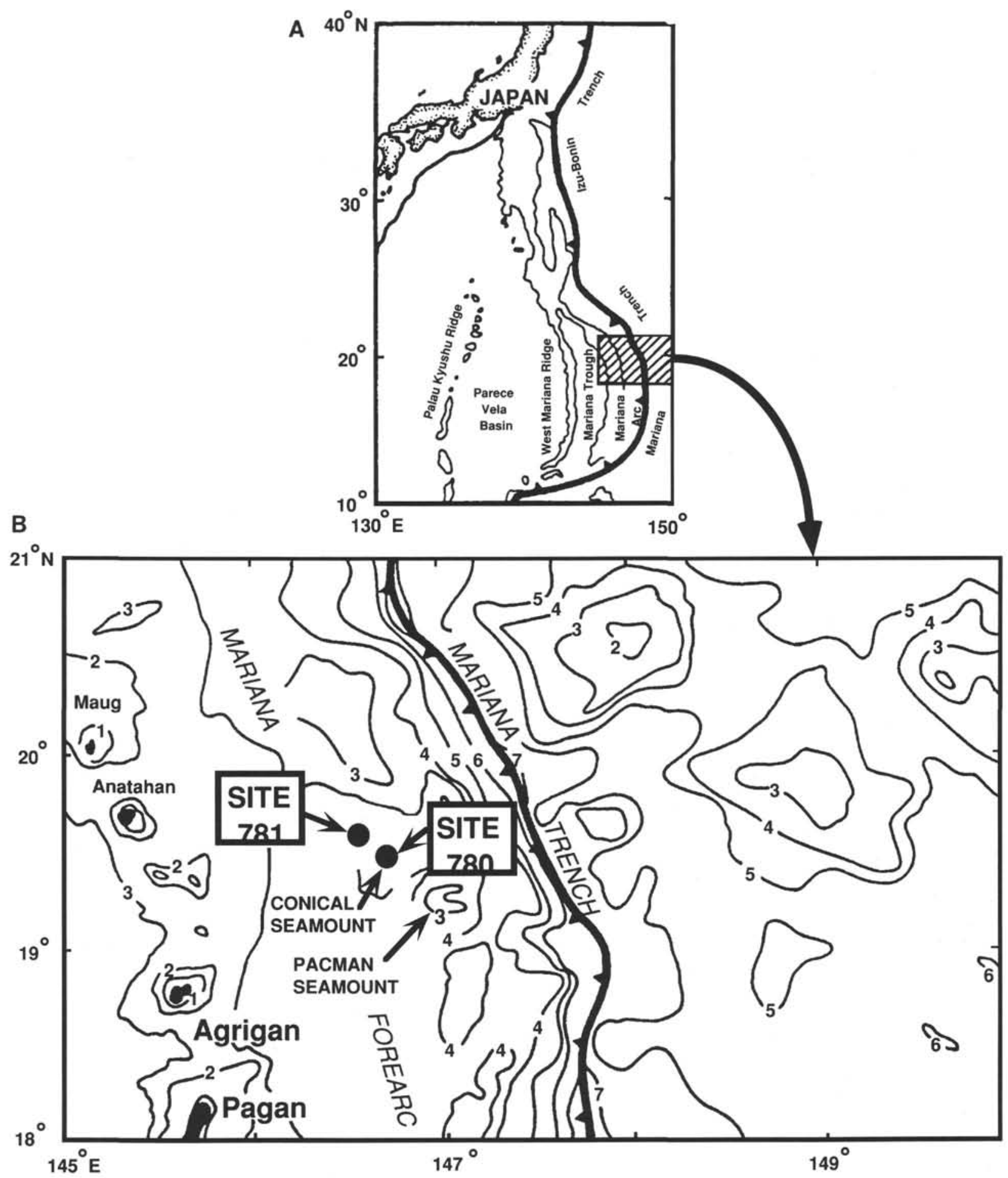

Figure 1. Location of Site 781. A. The regional setting of the Izu-Bonin and Mariana regions. B. Detailed setting of Site 781 showing the location of the Agrigan and Pagan islands and Conical and Pacman seamounts. Bathymetric contours in kilometers.

bounds the graben adjacent to Site 781 (Figs. 1 and 4). The plateau overlies the westward extension of the Dutton Ridge, a chain of Pacific seamounts that are gradually being subducted.

\section{Site $\mathbf{7 8 1}$}

Seismic-reflection surveys run between Sites $780\left(19^{\circ} 32.5^{\prime} \mathrm{N}\right.$, $\left.146^{\circ} 39.2^{\prime} \mathrm{E}\right)$ and $781\left(19^{\circ} 37.9^{\prime} \mathrm{N}, 146^{\circ} 32.5^{\prime} \mathrm{E}\right)$ in the Mariana forearc during Leg 125 revealed an anomalously bright reflection within a horst on the edge of a small graben located about $13 \mathrm{~km}$ northwest of Conical Seamount (Figs. 1-5; Marlow et al., 1990). Two seismicreflection profiles across the horst confirmed a high-amplitude reflection located at about $85 \mathrm{~ms}$ below seafloor (msbsf) (Figs. $3-5$ ). The reflection, originally thought to be from a forearc basement horizon, was first penetrated by the drill at $72 \mathrm{~m}$ below seafloor (mbsf) at Site 781 and found to be a basalt unit between 12.7 and $25 \mathrm{~m}$ thick 


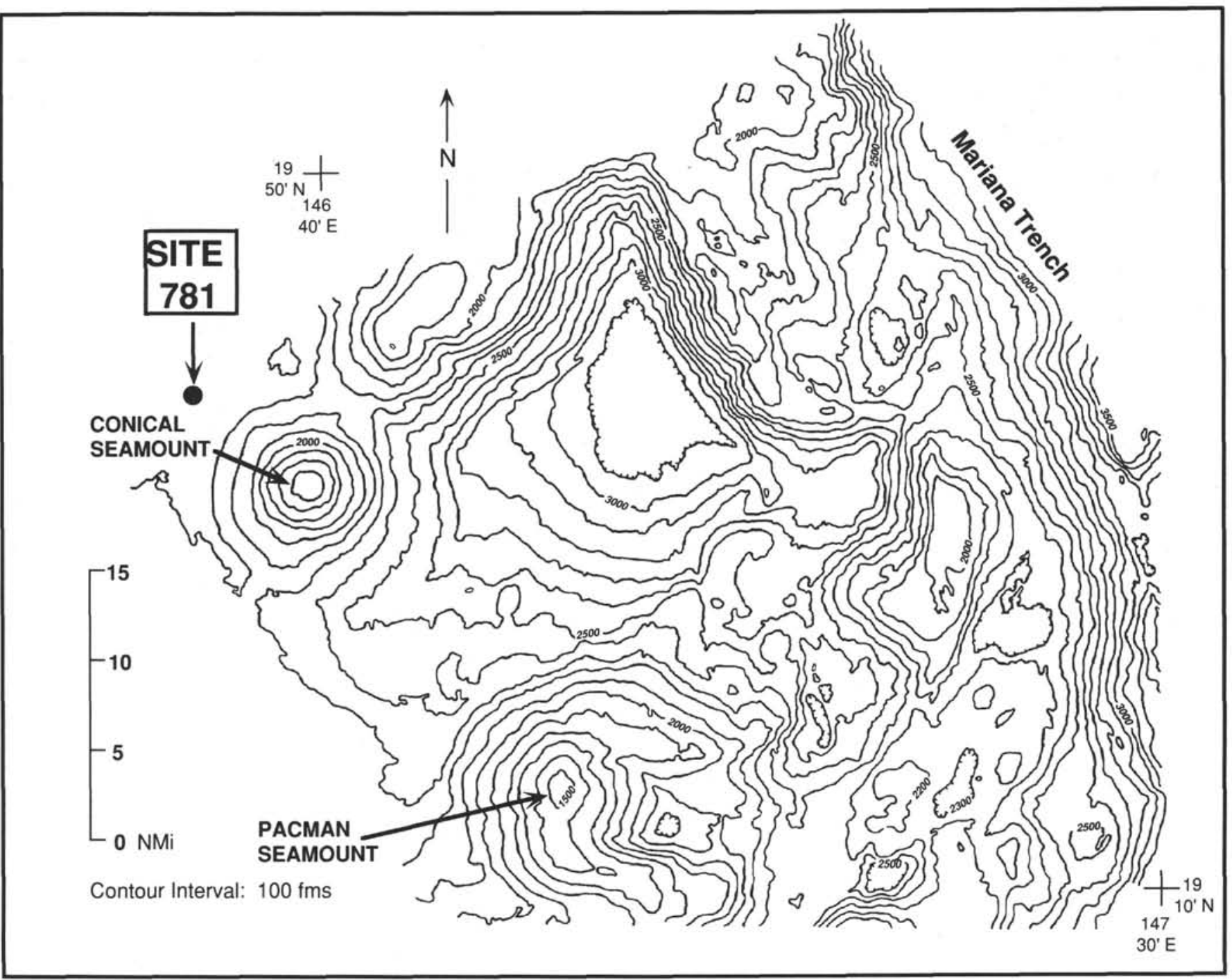

Figure 2. Detailed bathymetric map of the outer Mariana forearc near Site 781 and Conical Seamount. (Data from redigitized SeaMARC, SeaBeam, and 3.5-kHz records.)

(poor core recovery at its base did not allow us to measure the thickness accurately; Fryer, Pearce, Stokking, et al., 1990).

Here, we describe the volcano-tectonic setting of Site 781, as well as the seismic stratigraphy, petrology, and geochemistry of the basalt layer. We discuss the paleontologic, paleomagnetic, and K-Ar ages of the units drilled at Site 781. Finally, we speculate about the origin of the basalt and its implications for models of modern convergence zones.

\section{SEISMIC STRATIGRAPHY}

During Leg 125, a single-channel seismic-reflection survey was run along the flanks of Conical Seamount and across the adjacent forearc to find a suitable drill site to sample the forearc basement beneath the seamount. The survey used two small 80 -in. ${ }^{3}$ water guns fired every $12 \mathrm{~s}$ and data were recorded using a $100-\mathrm{m}$ streamer (Marlow et al., 1990).

Two single-channel seismic-reflection profiles were shot across Site 781 (Figs. 3-5; Marlow et al., 1990). The high-amplitude reflection, discovered during the first survey, is located at about $85 \mathrm{msbsf}$ at Site 781 within a horst structure adjacent to a small graben (Fig. 4). The 72-m-thick sedimentary sequence overlying the basalt has an average velocity of $1505 \mathrm{~m} / \mathrm{s}$ (Marlow et al., 1990). The layered reflections below the basalt on lines 4 and 5A (Figs. 4 and 5) are presumably from sedimentary sequences underlying the volcanic section (Fryer, Pearce, Stokking, et al., 1990).

On line 4 (Fig. 4), a second high-amplitude reflection was recorded beneath a layered sequence filling a small graben adjacent to the horst block at Site 781. The second reflection is vertically offset from the basalt layer reflection within the horst by about 100 to $150 \mathrm{~ms}$. One interpretation of the reflection geometry is shown in Figure 4, where the offset between reflections can be interpreted as faulting that postdates the lava.

Line 5A shows the high-amplitude reflections as an irregular and "rubbly looking" layer beneath well-layered, horizontal reflections from the overlying sedimentary sequence (Fig. 5). The irregular reflections are from the basalt layer drilled at Site 781 and can be traced laterally to a slightly deeper sub-bottom depth beneath the adjacent graben. In this profile, the basalt layer can be interpreted as extending laterally from the horst into the graben. The basalt layer may have continued horizontally as a sill within the horst, but dropped to a deeper level within the graben (Fig. 4), creating the apparent offset between the two high-amplitude reflections on this line. This second, favored interpretation suggests that the sill postdates the faulting along the edge of the graben. However, we cannot resolve whether the basalt layers are offset by faulting or if they occupy different levels in the section because of the sparse seismic-reflection data around Site 781 . 


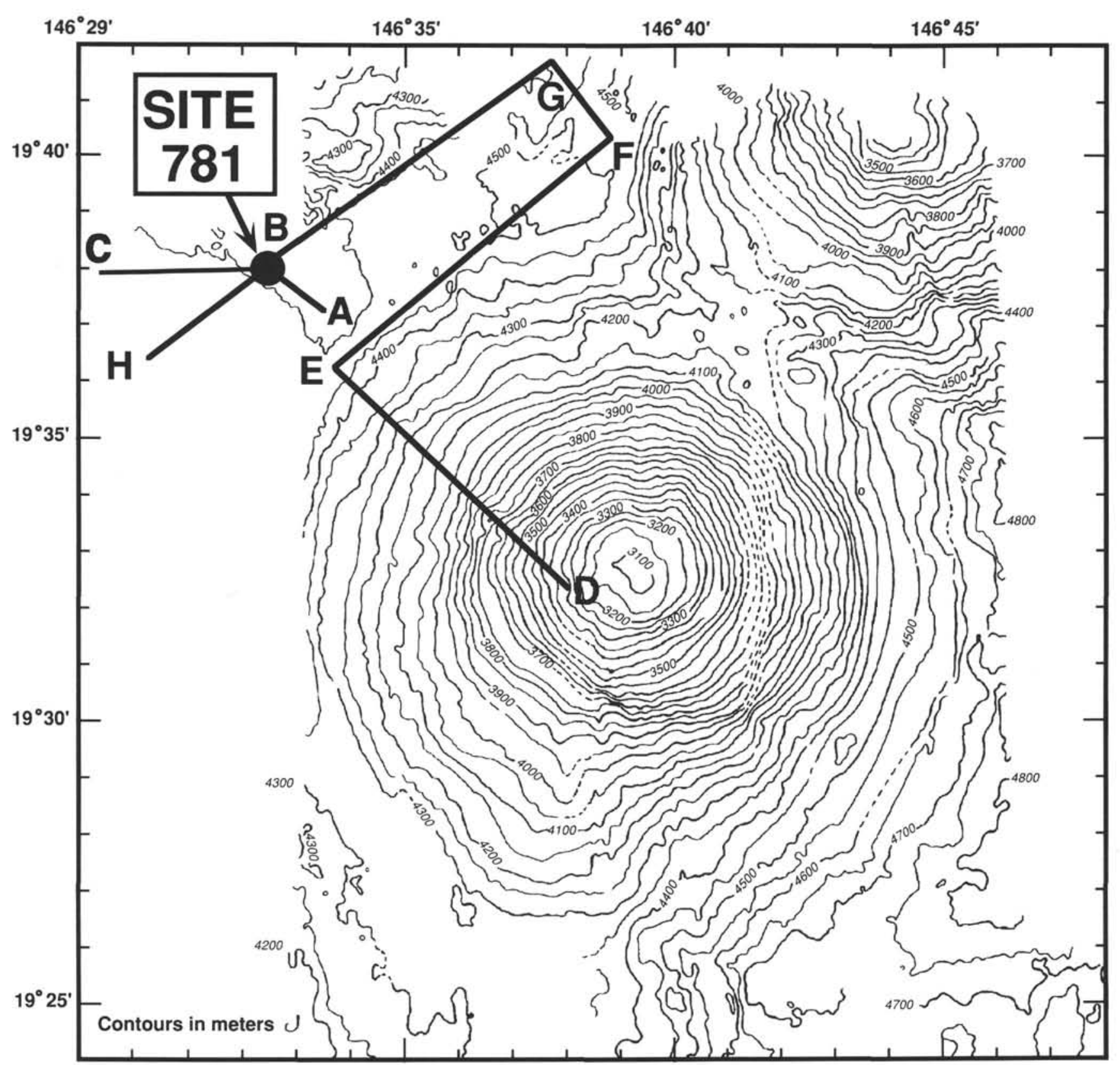

Figure 3. Trackline map of seismic-reflection profiles across Site 781 and Conical Seamount. Detailed bathymetry based on unpublished SeaBeam data collected by the University of Kiel.

\section{AGE OF THE BASALT}

The drill encountered three stratigraphic units at Site 781: an upper sedimentary unit extending from the seafloor to a depth of $72 \mathrm{mbsf}$, followed by a vesicular, porphyritic basalt layer to about $92 \mathrm{mbsf}$, that in turn is underlain by a second sedimentary unit that extends at least to the bottom of the hole at $250 \mathrm{mbsf}$. The upper sedimentary unit consists of late Pliocene (calcareous nannofossil Zone CN12b of Okada and Bukry, 1980) to Holocene age diatom-radiolarian silty clay that grades downward into vitric silty clay and vitric clayey silt (Fryer, Pearce, Stokking, et al., 1990). The lower sedimentary unit comprises early(?) Pliocene to late Pliocene age (nannofossil Subzone CN12b) vitric silty clay and vitric clayey silt (Fryer, Pearce, Stokking, et al., 1990).

Analyses for two K-Ar ages were performed at the U.S. Geological Survey (Menlo Park). Ages were calculated from six $\mathrm{K}_{2} \mathrm{O}$ analyses and two $\mathrm{Ar}$ analyses run on unaltered plagioclase separates from selected basalt core samples. The $\mathrm{K}_{2} \mathrm{O}$ analyses were $0.084,0.079$, $0.075,0.075,0.081$, and $0.082 \mathrm{wt} \%$ and averaged $0.079 \pm 0.004 \mathrm{wt} \%$. The first $\mathrm{Ar}$ analysis had $5.0 \%$ radiogenic ${ }^{40} \mathrm{Ar}$ and yielded an age of $1.58 \pm 0.40 \mathrm{Ma}$. The second $\mathrm{Ar}$ analysis had $2.1 \%$ radiogenic ${ }^{40} \mathrm{Ar}$ and yielded an age of $1.93 \pm 0.62 \mathrm{Ma}$. The errors are estimates of the standard deviations of analytical precision and are large mainly because of the low proportion of radiogenic to atmospheric argon-40, a common problem in very young igneous rocks. The average of the two analyses, weighted by the inverse of the variances of the individual runs, gives an age of $1.68 \pm 0.37 \mathrm{Ma}$.

All the recovered basalt cores are reversely polarized. The $\mathrm{K}-\mathrm{Ar}$ dating indicates that the rocks cooled through the Curie temperature during the Matuyama reversed polarity Chron ( 0.8 to 2.5 Ma; Fryer, Pearce, Stokking, et al., 1990). The late Pliocene age (nannofossil 

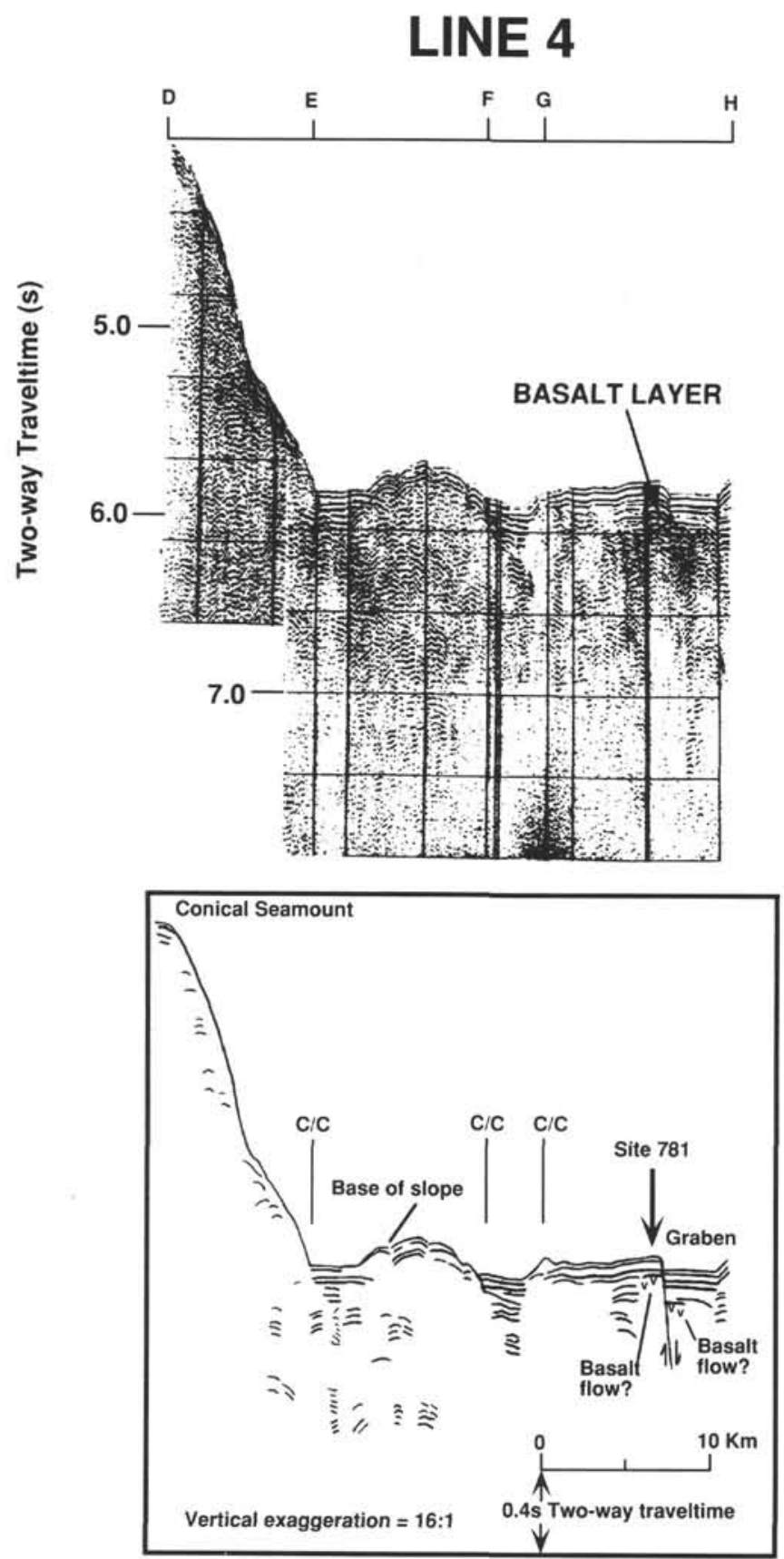

Figure 4. Seismic-reflection profile across the flank and along the base of Conical Seamount and across Site 781 and an adjacent graben, with an interpretative drawing of the profile. The high-amplitude reflector at about $85 \mathrm{~ms}$ (two-way traveltime) corresponds to the top of the basalt layer penetrated at Site 781 at $72 \mathrm{mbsf}$. A similar reflector in the adjacent graben is also interpreted as a volcanic layer. The two reflectors may be part of one volcanic unit that is either displaced by young faulting, as indicated here, or is continuous and joined out of the plane of this section. The latter hypothesis requires that the sill be intruded at two different depths in the graben and adjacent horst block (see Fig. 5 and text for discussion). The trackline location is shown in Figure 3.

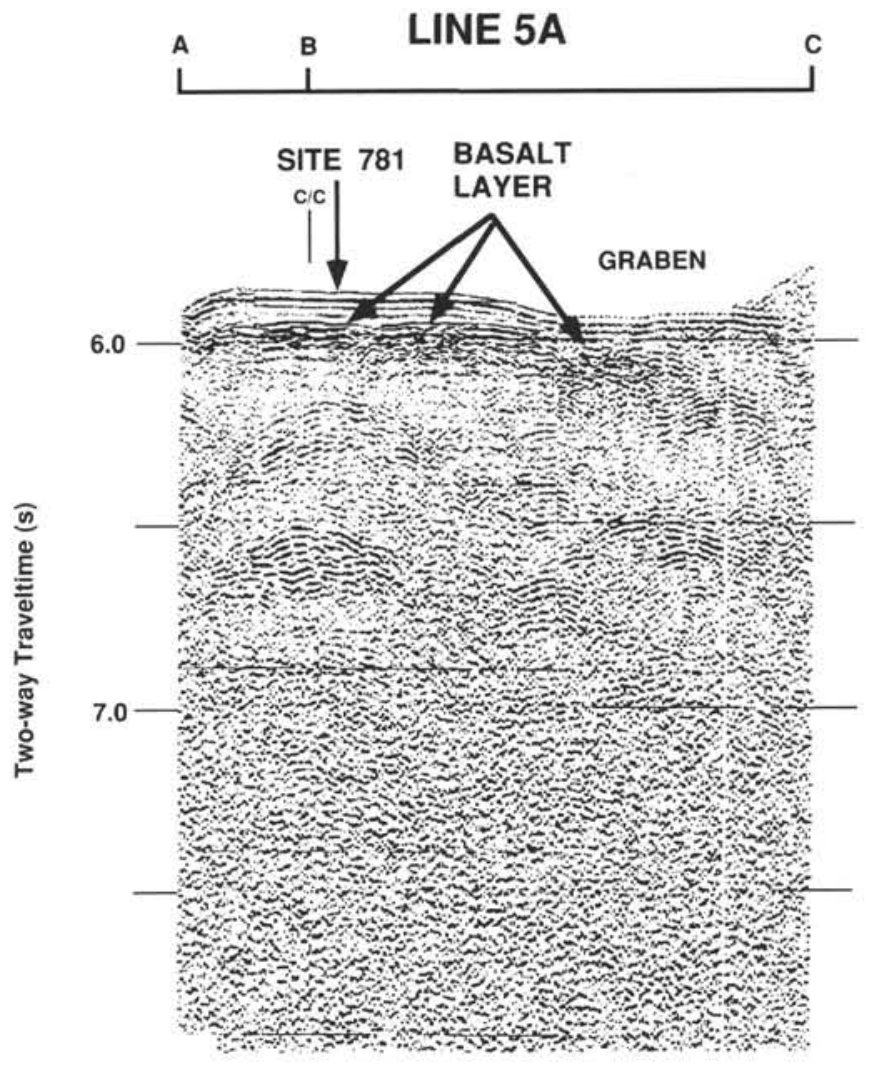

Figure 5. Processed, digital seismic-reflection data collected from survey line $5 \mathrm{~A}$ after leaving Site 781 . Automatic gain control was applied with processing filter parameters of 25 to $140 \mathrm{~Hz}$ and a filter length of $37 \mathrm{~Hz}$. The highamplitude reflector corresponds to the basalt layer drilled at Site 781, which can be traced laterally beneath the adjacent graben. The trackline location is shown in Figure 3.

Subzone $\mathrm{CN} 12 \mathrm{~b}$, about $2.5 \mathrm{Ma}$ ) sedimentary layers above and below the basalt layer are normally magnetized and, on the basis of their paleontologic ages, were deposited during the older Gauss normal polarity Chron (Fryer, Pearce, Stokking, et al., 1990). The age data support the initial interpretation that the basalt unit is a sill. The uniform magnetization, petrology, and geochemistry of the basalt drill cores and their schlierenlike structures suggest that the cores are from one continuous sill.

\section{PETROGRAPHY AND GEOCHEMISTRY OF SITE 781 BASALT}

\section{Analytical Procedures}

Geochemical data for the basalt samples from Site 781 are given in Tables 1 through 4. Major and trace element analyses of eight whole-rock samples were accomplished by X-ray fluorescence (XRF) both aboard JOIDES Resolution and at the University of Hawaii (Table 1). Rare earth element (REE) analyses of three samples were performed at Lamont-Doherty Geological Observatory by directly coupled plasma (DCP) spectrometry (Table 2). Analytical techniques are described herein and detailed descriptions of the techniques for the shipboard analyses are in Fryer, Pearce, Stokking, et al. (1990). 
Table 1. XRF-determined whole-rock major and trace element abundances, Hole 781A basalt layer.

\begin{tabular}{|c|c|c|c|c|c|c|c|c|}
\hline & $\begin{array}{c}8 \mathrm{R}-\mathrm{CC}, 9 \mathrm{R}- \\
1,9 \mathrm{R}-2, \\
11-13 \mathrm{~cm}\end{array}$ & $\begin{array}{c}9 \mathrm{R}-3, \\
69-71 \mathrm{~cm}\end{array}$ & $\begin{array}{c}10 \mathrm{R}-1, \\
49-51 \mathrm{~cm}\end{array}$ & $\begin{array}{c}10 \mathrm{R}-2, \\
88-92 \mathrm{~cm}\end{array}$ & $\begin{array}{c}10 \mathrm{R}-3, \quad 10 \mathrm{R}- \\
1, \\
84-86 \mathrm{~cm}\end{array}$ & $68-72 \mathrm{~cm}$ & $65-67 \mathrm{~cm}$ & $131-135 \mathrm{~cm}$ \\
\hline \multicolumn{9}{|c|}{ Oxides (wt\%) } \\
\hline $\mathrm{SiO}_{2}$ & 49.89 & 49.56 & 49.09 & 50.29 & 50.46 & 49.53 & 50.35 & 50.73 \\
\hline $\mathrm{TiO}_{2}^{2}$ & 0.86 & 0.88 & 0.85 & 0.91 & 0.89 & 0.85 & 0.90 & 0.91 \\
\hline $\mathrm{Al}_{2} \mathrm{O}_{3}$ & 17.87 & 17.69 & 17.31 & 17.79 & 17.10 & 17.57 & 17.28 & 18.17 \\
\hline${ }^{\mathrm{a}} \mathrm{Fe}_{2} \mathrm{O}_{3}$ & 12.09 & 12.43 & 12.03 & 12.45 & 12.36 & 12.02 & 12.73 & 11.93 \\
\hline $\mathrm{MnO}$ & 0.25 & 0.23 & 0.25 & 0.20 & 0.24 & 0.22 & 0.24 & 0.18 \\
\hline $\mathrm{MgO}$ & 4.21 & 4.40 & 4.45 & 4.64 & 4.25 & 4.45 & 4.45 & 4.56 \\
\hline $\mathrm{CaO}$ & 11.18 & 11.32 & 11.09 & 11.13 & 10.95 & 11.08 & 10.89 & 11.24 \\
\hline${ }^{b} \mathrm{Na}_{2} \mathrm{O}$ & 2.10 & 2.02 & 2.08 & 2.27 & 2.27 & 2.31 & 2.19 & 2.21 \\
\hline $\mathrm{K}_{2} \mathrm{O}$ & 0.52 & 0.42 & 0.43 & 0.42 & 0.58 & 0.39 & 0.50 & 0.35 \\
\hline $\mathrm{P}_{2} \mathrm{O}_{3}$ & 0.06 & 0.06 & 0.06 & 0.10 & 0.06 & 0.06 & 0.06 & 0.10 \\
\hline Total & 99.03 & 99.01 & 97.64 & 100.20 & 99.05 & 98.48 & 99.59 & 100.38 \\
\hline LOI & 0.64 & 1.28 & 0.86 & nd & 1.95 & 0.75 & 0.79 & nd \\
\hline
\end{tabular}

Trace elements (ppm)

\begin{tabular}{lrrrrrrrr}
$\mathrm{Nb}$ & 1 & 1 & 1 & 1 & 1 & 1 & 1 & 1 \\
$\mathrm{Zr}$ & 48 & 46 & 46 & 47 & 52 & 46 & 49 & 48 \\
$\mathrm{Y}$ & 23 & 22 & 22 & 21 & 24 & 22 & 23 & 22 \\
$\mathrm{Sr}$ & 294 & 294 & 295 & 287 & 288 & 294 & 293 & 285 \\
$\mathrm{Rb}$ & 7 & 6 & 4 & 8 & 13 & 2 & 7 & 3 \\
$\mathrm{Zn}$ & 98 & 92 & 71 & 90 & 94 & 77 & 82 & 78 \\
$\mathrm{Cu}$ & 175 & 184 & 72 & 197 & 181 & 141 & 196 & 133 \\
$\mathrm{Ni}$ & 7 & 9 & 10 & 11 & 11 & 11 & 10 & 12 \\
$\mathrm{Cr}$ & 11 & 11 & 11 & 43 & 8 & 9 & 11 & 19 \\
$\mathrm{~V}$ & 407 & 428 & 387 & 374 & 354 & 408 & 370 & 392 \\
$\mathrm{Ce}$ & 18 & 32 & 15 & nd & 17 & 26 & 23 & nd \\
$\mathrm{Ba}$ & 169 & 142 & 165 & 196 & 158 & 280 & 177 & 159 \\
\hline
\end{tabular}

Note: Analyses performed aboard JOIDES Resolution by D. Sims except for Samples 125-781A-9R-3, 88-92 cm, and 125-781A10R-1, 131-135 cm, which were analyzed at the University of Hawaii by T. Hulsebosch and L. Johnson. nd $=$ not determined. Total iron calculated as $\mathrm{Fe}_{2} \mathrm{O}_{3}$.

${ }^{\text {b }}$ Shipboard-determined values corrected on the basis of the factor determined by Arculus et al. (this volume).

Powders were prepared from rocks washed in distilled water, chipped to pieces less than $0.5 \mathrm{~cm}$ in size, and powdered in an alumina mill (University of Hawaii) or a WC mill (shipboard). Fused glass disks (major elements) and pressed powder pellets (trace elements) were prepared and on-line data reduction accomplished using the methods of Norrish and Hutton (1969) and Norrish and Chappell (1977). Glass disks were prepared from rock powders ignited at $950^{\circ} \mathrm{C}$ (University of Hawaii) or $1030^{\circ} \mathrm{C}$ (shipboard) to drive off volatiles, mixed with a lithium meta-borate flux, and fused at $1000^{\circ} \mathrm{C}$ (University of Hawaii) or $1150^{\circ} \mathrm{C}$ (shipboard). Volatiles are listed in Table 1 as loss on ignition (LOI). Pressed pellets were prepared from $\sim 5 \mathrm{~g}$ of rock powder, mixed with a polyvinyl alcohol binder and pressed into a boric acid casing (University of Hawaii) or an aluminum cap (shipboard). Two systematic errors were observed in the shipboard data. $\mathrm{Na}$ and $\mathrm{Ti}$ values appear to be low. $\mathrm{Na}_{2} \mathrm{O}$ values were corrected for all samples in Table 1 either by new analyses or by using an empirical factor. See Arculus et al. (this volume) for a complete discussion. $\mathrm{TiO}_{2}$ values were not corrected. A comparison of shipboard analyses with shore-based analyses suggests that the former are low by only $0.01 \%$ to $0.02 \%$.

REE analyses were performed on rock powders ignited at $950^{\circ} \mathrm{C}$, mixed with an ultrapure lithium meta-borate (Mathey-Johnston, Puratronic) flux, fused in a graphite crucible at $1060^{\circ} \mathrm{C}$, and dissolved in $1 \mathrm{~N} \mathrm{HCl}$. This solution was filtered to remove graphite particles and washed onto cation exchange columns (filled with 200-400-mesh analytical grade resin) with ultrapure water for REE separation. Concentrated REE samples were dried overnight in Teflon beakers, redissolved in a $1 \mathrm{~N} \mathrm{HNO}_{3}$ solution spiked with $\mathrm{K}, \mathrm{P}$, and $\mathrm{Be}$, and analyzed by DCP spectrometry. The $\mathrm{P}$ and Be were used as internal standards to correct for short-term drift, whereas $\mathrm{K}$ acted as a signal enhancer. Distilled reagent-grade acids diluted with ultrapure water were used for all phases of REE analyses. Data reduction included blank subtraction, correction for long- and short-term drift, and known elemental interferences. Absolute abundances were determined by comparison to two basaltic standards (K1919 and AII-9229 ), and precision was determined from repeat analyses of several samples as unknowns. The precision for repeat analyses of a MidAtlantic Ridge basalt is listed in Table 2 and has $<2 \%$ standard deviation ([1 standard deviation/average value] $\times 100$ ) for all elements. Because of a random, sporadic La contamination problem, the $\mathrm{La}$ values for all samples are suspect and were included only where independent or duplicate information is available.

The basalt was also analyzed for incompatible trace elements by inductively coupled plasma/mass spectrometry (ICP-MS) at Durham University (for analytical methods, see Murton et al., this volume) and for $\mathrm{Sr}, \mathrm{Nd}$, and $\mathrm{Pb}$ isotopic ratios (Table 3 ) by mass spectrometry at Royal Holloway and Bedford New Colleges, London (for analytical methods, see Pearce et al., this volume).

Microprobe analyses of mineral phases were performed for three thin sections from the uppermost (Sample 125-781A-9R-1, 0-4 cm), central (Sample 125-781A-10R-1, 16-20 cm), and lowermost (Sample 125-781A-10R-3, 17-21 cm) portions of the igneous unit. Analysis at the University of Hawaii was performed on a fully automated, three-spectrometer Cameca microprobe using the methods of Byerly et al. (1977; Table 4). For mineral analyses, the beam was focused to its smallest possible diameter, approximately $2 \mu \mathrm{m}$, counting time was $20 \mathrm{~s} / \mathrm{spot}$, and a beam current of $10-15 \mathrm{nA}$ at 15 $\mathrm{kV}$ was used. Where possible, calibration was accomplished on 
Table 2. REE analyses of representative samples (ppm), Hole 781A basalt layer.

\begin{tabular}{cccccc}
\hline & $\begin{array}{c}\text { 9R-1, } \\
69-71 \mathrm{~cm}\end{array}$ & $\begin{array}{c}\text { 10R-2, } \\
68-71 \mathrm{~cm}\end{array}$ & $\begin{array}{c}\text { 10R-3, } \\
65-67 \mathrm{~cm}\end{array}$ & $\begin{array}{c}\text { Standard } \\
\text { deviation } \\
(\%)\end{array}$ & $\begin{array}{c}\text { Chondrite } \\
\text { normalization }\end{array}$ \\
\hline $\mathrm{La}$ & 2.89 & 3.37 & 3.17 & nd & 0.315 \\
$\mathrm{Ce}$ & 8.54 & 9.11 & 9.46 & 1.9 & 0.813 \\
$\mathrm{Nd}$ & 6.19 & 7.60 & 7.44 & 1.7 & 0.597 \\
$\mathrm{Sm}$ & 2.09 & 2.51 & 2.42 & 1.9 & 0.192 \\
$\mathrm{Eu}$ & 0.81 & 0.92 & 0.92 & 0.5 & 0.072 \\
$\mathrm{Gd}$ & 2.92 & 2.99 & 3.18 & 0.4 & 0.259 \\
$\mathrm{Dy}$ & 2.80 & 3.58 & 3.48 & 1.6 & 0.325 \\
$\mathrm{Er}$ & 1.82 & 2.56 & 2.23 & 1.2 & 0.214 \\
$\mathrm{Yb}$ & 1.80 & 2.26 & 2.20 & 1.6 & 0.208 \\
$\mathrm{Lu}$ & 0.30 & 0.36 & 0.34 & 1.9 & 0.032 \\
\hline
\end{tabular}

Note: Data determined using directly coupled plasma at Lamont-Doherty Geological Observatory by $\mathrm{L}$. Johnson. nd = not determined.

a' $(1$ standard deviation/average $) \times 100$ for four analyses of a Mid-Atlantic Ridge basalt. ${ }^{b}$ Chondrite factor used from Figure 2.

Table 3. Incompatible elements, REE, and isotopic ratios, basalt layer, Sample 125-781A-9R-1, 72-77 cm.

\begin{tabular}{llll}
\hline $\begin{array}{l}\text { Incompatible } \\
\text { elements (ppm) }\end{array}$ & \multicolumn{2}{l}{ REE $^{\mathrm{a}}$ (ppm) } \\
\hline $\mathrm{Zr}$ & 43 & $\mathrm{La}$ & 3.62 \\
$\mathrm{Y}$ & 19.4 & $\mathrm{Ce}$ & 7.64 \\
$\mathrm{Nb}$ & 1.8 & $\mathrm{Pr}$ & 1.2 \\
$\mathrm{Hf}$ & 1.37 & $\mathrm{Nd}$ & 6.15 \\
$\mathrm{Ta}$ & 0.12 & $\mathrm{Sm}$ & 2.16 \\
$\mathrm{~Pb}$ & 2.52 & $\mathrm{Eu}$ & 0.79 \\
$\mathrm{Th}$ & 0.18 & $\mathrm{Gd}$ & 2.73 \\
$\mathrm{U}$ & 0.20 & $\mathrm{~Tb}$ & 0.43 \\
$\mathrm{Sr}$ & 270 & $\mathrm{Dy}$ & 2.84 \\
$\mathrm{Ba}$ & 156 & $\mathrm{Ho}$ & 0.60 \\
& & $\mathrm{Er}$ & 1.70 \\
& & $\mathrm{Tm}$ & 0.30 \\
& & $\mathrm{Yb}$ & 1.79 \\
& & $\mathrm{Lu}$ & 0.30
\end{tabular}

Isotopic ratios

$\begin{array}{ll}{ }^{87} \mathrm{Sr} /{ }^{86} \mathrm{Sr} & 0.703487 \pm 0.000010 \\ { }^{143} \mathrm{Nd} /{ }^{144} \mathrm{Nd} & 0.513048 \pm 0.000004 \\ { }^{206} \mathrm{~Pb} /{ }^{204} \mathrm{~Pb} & 18.740 \\ { }^{207} \mathrm{~Pb} /{ }^{204} \mathrm{~Pb} & 15.569 \\ { }^{208} \mathrm{~Pb} /{ }^{204} \mathrm{~Pb} & 38.386\end{array}$

"ICP-MS performed at Durham University by B. Murton.

MS performed at Royal Holloway and Bedford New Colleges, London, by J. A. Pearce. The sample was leached in $6 \mathrm{~N} \mathrm{HCl}$ for $3 \mathrm{hr}$ at $180^{\circ} \mathrm{C}$ for $\mathrm{Sr}$ isotope analysis.

natural minerals of the same phase as that analyzed. The final data were corrected by comparison to repeat analyses of known values of standard minerals and adjusted linearly for drift.

\section{Petrography}

The basalt sill is predominantly hypocrystalline with intersertal and intergranular to subophitic textures. Vesicles range from 0.1 to $4 \mathrm{~mm}$ in diameter and make up 5\% to $10 \%$ of the rock. An 8-mmthick, vesicle-free chill zone is present at the top of the sill, and sparse, very fine-grained, crystal-free zones (e.g., Section 125-781A-10R-1, $17-21 \mathrm{~cm}$ ) are present throughout the sill. The basalt is fresh except for a small amount of amorphous clay, present after glassy matrix, at the base of the recovered unit. Glomerocrysts up to $5 \mathrm{~mm}$ in diameter are common and are typically composed solely of plagioclase, although about one-third includes clinopyroxene and sparse olivine; opaque phases are less abundant. Individual plagioclase crystals in glomerocrysts are typically multiply twinned, euhedral to subhedral laths that range from 0.3 to $1.5 \mathrm{~mm}$ long. A few solitary plagioclase phenocrysts are present and are nearly always euhedral. Plagioclase crystals exhibit normal, reverse, and oscillatory zoning, with evidence for relict cores and irregular (partly resorbed?) crystal boundaries. Clinopyroxene and olivine crystals occur in glomerocrysts that have been completely surrounded or, more commonly, surrounded on three sides by crystals of plagioclase. Individual clinopyroxene crystals are 0.1 to $0.4 \mathrm{~mm}$, rounded to subhedral, and usually have irregular crystal boundaries. The absence of a quench texture suggests they were not in equilibrium with the surrounding melt when the sill cooled. Single clinopyroxene crystals commonly contain fractures filled with glass. Olivine is ubiquitous as small, rounded, anhedral crystals that are usually fractured and altered. Magnetite is common as angular to irregular crystals ( $<0.05 \mathrm{~mm}$ ), increases in abundance downcore, and is rarely included in single plagioclase or pyroxene grains. This crystal assemblage is set in a fine-grained groundmass of plagioclase, clinopyroxene, and olivine microlites that are in turn set in a dark brown glass. The modal percentage of plagioclase increases toward the center of the unit from $21 \%$ to $31 \%$ and then decreases toward the base to $24 \%$. Clinopyroxene ranges from $1.2 \%$ to $5 \%$ and does not vary systematically throughout the core. Opaque phases comprise $3.0 \%$ to $4.5 \%$ and olivine is $<1.5 \%$. Glass + matrix (clinopyroxene + plagioclase) accounts for $55 \%$ to $65 \%$ of the rock; locally, glass comprises $20 \%$ to $45 \%$, plagioclase $20 \%$ to $25 \%$, and clinopyroxene $20 \%$ to $25 \%$.

\section{Mineral Chemistry}

Three types of crystals, (microphenocrysts, phenocrysts, and individual crystals within glomerocrysts) consisting of plagioclase, pyroxene, olivine, and $\mathrm{Fe}$-oxide were analyzed to determine compositional variability (1) between single crystals within a glomerocryst, (2) between crystal types, and (3) vertically within the sill (Table 4 and Fig. 6). All data points are plotted on Figure 6, but only selected analyses are presented in Table 4 . A complete set of analyses may be obtained from the ODP data bases.

Total variability in the plagioclase compositions ranges from $\mathrm{An}_{41}$ to $\mathrm{An}_{97}$. Minimum values of $\mathrm{An}$ decrease downhole in microphenocrysts, from 66 in Sample 125-781A-9R-1, 0-4 cm, to 41 in Sample 125-781A-10R-3, 17-21 cm, and in phenocrysts, from 68 in Sample 125-781A-9R-1, 0-4 cm, to 55 in Sample 125-781A-10R-3, $17-21 \mathrm{~cm}$. Maximum values of An are similar downhole for phenocrysts (91-97), but decrease (from 82 in Sample 125-781A-9R-1, $0-4 \mathrm{~cm}$, to 66 in Sample 125-781A-10R-3, 17-21 cm) for microphenocrysts. Microphenocrysts are generally lower in An (41-82) than are phenocrysts (55-97). Zoning is common and usually normal; however, one crystal in Sample 125-781A-9R-1, 0-4 cm, was reversely zoned with $\mathrm{An}_{70}$ (core) and $\mathrm{An}_{90}$ (rim).

Clinopyroxenes are homogeneous and plot primarily in the augite region of the pyroxene quadrilateral (Fig. 6; Poldervaart and Hess, 1951). The total range of clinopyroxene compositions is $\mathrm{Wo}_{29-46}$, $\mathrm{En}_{32-47}$, and $\mathrm{Fs}_{10-37}$. The clinopyroxenes are homogeneous and unzoned. There are no systematic differences among microphenocrysts, phenocrysts, and individual crystals within glomerocrysts (Table 4). Although the total range of compositional variability is similar, the microphenocrysts exhibit a greater variability within a single thin section than do phenocrysts and glomerocrysts. The greatest variability of En and Fs is found in the center of the section (Sample $125-781 \mathrm{~A}-10 \mathrm{R}-1,16-20 \mathrm{~cm}$ ); however, the greatest variability in Wo content is found near the bottom.

Olivine grains commonly occur as individual crystals, which are unzoned and do not vary in composition downhole. Phenocrysts range from $\mathrm{Fo}_{69}$ to $\mathrm{Fo}_{71}$; one microphenocryst has $\mathrm{Fo}_{47}$.

All oxide phases analyzed are titanomagnetite; the $\mathrm{TiO}_{2}$ content increases downhole. The crystals from the upper part of the core are less titaniferous $\left(8.5 \% \mathrm{TiO}_{2}\right)$ than those at the base $\left(13 \% \mathrm{TiO}_{2}\right)$, and an inverse relationship was observed with $\mathrm{Cr}_{2} \mathrm{O}_{3}(0.6 \%$ vs. $0.1 \%)$. 
Table 4. Mineral analyses and calculated cation proportions.

Plagioclase

125-781A-9R-1, 0-4 cm

\begin{tabular}{|c|c|c|c|c|c|c|c|c|c|}
\hline $\begin{array}{l}\text { Grain } \\
\text { type }\end{array}$ & Microphenocryst & Microphenocryst & $\begin{array}{l}3-1 \\
\text { Rim }\end{array}$ & $\begin{array}{c}3-3 \\
\text { Core }\end{array}$ & $\begin{array}{l}3-3 \\
\text { Rim }\end{array}$ & $\begin{array}{c}4-1 \\
\text { Core }\end{array}$ & $\begin{array}{c}4-1 \\
\text { Rim }\end{array}$ & $\begin{array}{c}5 \\
\text { Core }\end{array}$ & $\begin{array}{c}5 \\
\text { Rim }\end{array}$ \\
\hline $\mathrm{SiO}_{2}$ & 51.76 & 48.04 & 45.28 & 46.92 & 49.12 & 48.93 & 52.11 & 51.47 & 47.65 \\
\hline $\mathrm{FeO}$ & 1.03 & 0.76 & 0.77 & 0.74 & 0.75 & 0.74 & 0.96 & 0.81 & 0.78 \\
\hline $\mathrm{MgO}$ & 1.07 & 0.10 & nd & 0.07 & 0.13 & 0.09 & 1.10 & 0.11 & 0.07 \\
\hline $\mathrm{CaO}$ & 13.77 & 16.65 & 18.12 & 17.56 & 15.63 & 16.18 & 13.40 & 13.75 & 16.28 \\
\hline $\mathrm{Na}_{2} \mathrm{O}$ & 3.89 & 1.97 & 0.36 & 1.34 & 2.50 & 2.36 & 2.96 & 3.54 & 1.84 \\
\hline
\end{tabular}

Ideal mineral proportions

$\begin{array}{lrrrrrrrrr}\text { An } & 65.87 & 82.07 & 96.47 & 87.81 & 77.37 & 78.89 & 71.04 & 67.78 & 82.72 \\ \mathrm{Ab} & 33.67 & 17.57 & 3.47 & 12.13 & 22.39 & 20.82 & 28.40 & 31.58 & 16.92 \\ \mathrm{Or} & 0.46 & 0.35 & 0.06 & 0.06 & 0.24 & 0.29 & 0.57 & 0.65 & 0.36\end{array}$

Cations in formula

\begin{tabular}{|c|c|c|c|c|c|c|c|c|c|}
\hline $\mathrm{Si}$ & 2.31 & 2.18 & 2.09 & 2.14 & 2.24 & 2.22 & 2.34 & 2.33 & 2.19 \\
\hline $\mathrm{Al}$ & 1.63 & 1.80 & 1.91 & 1.85 & 1.74 & 1.76 & 1.62 & 1.65 & 1.80 \\
\hline $\mathrm{Fe}$ & 0.04 & 0.03 & 0.03 & 0.03 & 0.03 & 0.03 & 0.04 & 0.03 & 0.03 \\
\hline $\mathrm{Mg}$ & 0.07 & 0.00 & 0.00 & 0.00 & 0.00 & 0.00 & 0.07 & 0.00 & 0.00 \\
\hline $\mathrm{Ca}$ & 0.66 & 0.81 & 0.90 & 0.86 & 0.76 & 0.79 & 0.64 & 0.67 & 0.80 \\
\hline $\mathrm{Na}$ & 0.34 & 0.17 & 0.03 & 0.12 & 0.22 & 0.21 & 0.26 & 0.31 & 0.16 \\
\hline K & 0.00 & 0.00 & 0.00 & 0.00 & 0.00 & 0.00 & 0.00 & 0.00 & 0.00 \\
\hline
\end{tabular}

$125-781 \mathrm{~A}-10 \mathrm{R}-1,16-20 \mathrm{~cm}$

\begin{tabular}{|c|c|c|c|c|c|c|c|c|}
\hline $\begin{array}{l}\text { Grain } \\
\text { type }\end{array}$ & Microphenocryst & Microphenocryst & $\begin{array}{c}1-1 \\
\text { Core }\end{array}$ & $\begin{array}{l}1-1 \\
\text { Rim }\end{array}$ & $\begin{array}{c}1-3 \\
\text { Core }\end{array}$ & $\begin{array}{l}1-3 \\
\text { Rim }\end{array}$ & $\begin{array}{c}4-1 \\
\text { Core }\end{array}$ & $\begin{array}{l}4-1 \\
\text { Rim }\end{array}$ \\
\hline $\mathrm{SiO}_{2}$ & 50.78 & 57.20 & 45.85 & 51.10 & 45.52 & 49.52 & 45.98 & 48.78 \\
\hline $\mathrm{Al}_{2} \mathrm{O}_{3}$ & 31.22 & 26.84 & 34.89 & 30.71 & 35.47 & 32.99 & 34.31 & 32.39 \\
\hline $\mathrm{FeO}$ & 0.86 & 0.73 & 0.73 & 0.88 & 0.73 & 0.84 & 0.77 & 0.78 \\
\hline $\mathrm{MgO}$ & 0.09 & 0.03 & 0.06 & 0.09 & 0.06 & 1.07 & 0.11 & 0.08 \\
\hline $\mathrm{CaO}$ & 14.21 & 9.04 & 18.54 & 14.04 & 18.59 & 16.25 & 17.90 & 15.53 \\
\hline $\mathrm{Na}_{2} \mathrm{O}$ & 3.42 & 5.34 & 1.63 & 3.59 & 1.05 & 2.38 & 1.48 & 1.92 \\
\hline $\mathrm{K}_{2} \mathrm{O}$ & 0.10 & 0.21 & 0.03 & 0.10 & nd & 0.05 & nd & 0.06 \\
\hline Total & 100.68 & 99.39 & 101.73 & 100.51 & 101.42 & 103.10 & 100.55 & 99.54 \\
\hline \multicolumn{9}{|c|}{ Ideal mineral proportions } \\
\hline An & 69.26 & 47.70 & 86.13 & 67.97 & 90.67 & 78.82 & 86.88 & 81.41 \\
\hline $\mathrm{Ab}$ & 30.16 & 50.98 & 13.70 & 31.45 & 9.27 & 20.89 & 13.00 & 18.21 \\
\hline Or & 0.58 & 1.32 & 0.17 & 0.58 & 0.06 & 0.29 & 0.12 & 0.37 \\
\hline
\end{tabular}

Cations in formula

\begin{tabular}{lllllllll}
$\mathrm{Si}$ & 2.31 & 2.58 & 2.09 & 2.32 & 2.08 & 2.21 & 2.11 & 2.24 \\
$\mathrm{Al}$ & 1.67 & 1.43 & 1.87 & 1.65 & 1.91 & 1.73 & 1.86 & 0.03 \\
$\mathrm{Fe}$ & 0.03 & 0.03 & 0.03 & 0.03 & 0.03 & 0.03 & 0.03 & 0.00 \\
$\mathrm{Mg}$ & 0.00 & 0.00 & 0.00 & 0.00 & 0.00 & 0.07 & 0.00 \\
$\mathrm{Ca}$ & 0.69 & 0.44 & 0.91 & 0.68 & 0.91 & 0.78 & 0.88 & 0.76 \\
$\mathrm{Na}$ & 0.30 & 0.47 & 0.14 & 0.32 & 0.09 & 0.21 & 0.13 & 0.00 \\
$\mathrm{~K}$ & 0.00 & 0.00 & 0.00 & 0.00 & 0.00 & 0.00 & 0.00 \\
\hline
\end{tabular}

125-781A-10R-3,17-21 cm

\begin{tabular}{lccrrrrrr}
$\begin{array}{l}\text { Grain } \\
\text { type }\end{array}$ & Microphenocryst & Microphenocryst & $\begin{array}{c}1 \\
\text { Core }\end{array}$ & $\begin{array}{c}1 \\
\text { Rim }\end{array}$ & $\begin{array}{c}\text { Core } \\
\text { Core }\end{array}$ & $\begin{array}{c}3 \\
\text { Rim }\end{array}$ & $\begin{array}{c}4 \\
\text { Core }\end{array}$ & $\begin{array}{c}4 \\
\text { Rim }\end{array}$ \\
\hline $\mathrm{SiO}_{2}$ & 52.81 & 58.70 & 48.85 & 53.09 & 46.14 & 51.60 & 46.61 \\
$\mathrm{Al}_{2} \mathrm{O}_{3}$ & 29.09 & 26.15 & 32.80 & 29.78 & 35.05 & 30.03 & 34.05 & 48.55 \\
$\mathrm{FeO}$ & 0.61 & 0.49 & 0.69 & 0.65 & 0.62 & 1.28 & 0.70 & 32.83 \\
$\mathrm{MgO}$ & 0.08 & 1.01 & 0.12 & 0.07 & 0.08 & 0.32 & 0.06 & 1.07 \\
$\mathrm{CaO}$ & 12.39 & 8.05 & 16.34 & 12.73 & 18.53 & 13.33 & 17.45 & 1.48 \\
$\mathrm{Na}_{2} \mathrm{O}$ & 3.54 & 6.34 & 2.13 & 4.17 & 0.46 & 2.94 & 2.31 \\
$\mathrm{~K}_{2} \mathrm{O}$ & 0.11 & 0.20 & 0.03 & 0.08 & 0.03 & 0.07 & 0.03 & 0.06 \\
Total & 98.63 & 100.94 & 100.96 & 100.57 & 100.91 & 99.57 & 100.38 & 101.54
\end{tabular}

Ideal mineral proportions

$\begin{array}{lrrrrrrrr}\mathrm{An} & 65.46 & 40.74 & 80.77 & 62.49 & 95.52 & 71.16 & 86.54 & 78.91 \\ \mathrm{Ab} & 33.85 & 58.06 & 19.05 & 37.04 & 4.29 & 28.40 & 13.28 & 20.73 \\ \mathrm{Or} & 0.69 & 1.21 & 0.18 & 0.47 & 0.18 & 0.44 & 0.18 & 0.35\end{array}$


Table 4 (continued).

125-781A-10R-3, 17-21 cm

\begin{tabular}{lccccccc}
$\begin{array}{l}\text { Grain } \\
\text { type }\end{array}$ & Microphenocryst & Microphenocryst & $\begin{array}{c}1 \\
\text { Core }\end{array}$ & $\begin{array}{c}1 \\
\text { Rim }\end{array}$ & $\begin{array}{c}3 \\
\text { Core }\end{array}$ & $\begin{array}{c}3 \\
\text { Rim }\end{array}$ & $\begin{array}{c}4 \\
\text { Core }\end{array}$ \\
\hline Cations in formula \\
\end{tabular}

Clinopyroxene

$125-781 \mathrm{~A}-9 \mathrm{R}-1,0-4 \mathrm{~cm}$

\begin{tabular}{|c|c|c|c|c|c|c|c|c|c|}
\hline $\begin{array}{l}\text { Grain } \\
\text { type }\end{array}$ & Microphenocryst & Phenocryst & $\begin{array}{c}1 \\
\text { Core }\end{array}$ & $\begin{array}{c}1 \\
\text { Core }\end{array}$ & $\begin{array}{c}1 \\
\operatorname{Rim}\end{array}$ & $\stackrel{4}{\text { Core }}$ & $\begin{array}{c}\text { Micro- } \\
\text { phenocryst }\end{array}$ & $\begin{array}{c}\text { Pheno- } \\
\text { cryst }\end{array}$ & $\begin{array}{c}2 \\
\text { Core }\end{array}$ \\
\hline $\mathrm{SiO}_{2}$ & 50.40 & 52.06 & 51.45 & 52.64 & 51.96 & 49.11 & 51.50 & 50.65 & 51.43 \\
\hline $\mathrm{Al}_{2} \mathrm{O}$ & 4.27 & 2.88 & 2.21 & 2.29 & 2.75 & 4.32 & 1.79 & 3.34 & 1.60 \\
\hline $\mathrm{TiO}_{2}$ & 0.71 & 0.44 & 0.31 & 0.30 & 0.30 & 0.90 & 0.47 & 0.57 & 0.38 \\
\hline $\mathrm{FeO}^{2}$ & 12.22 & 11.73 & 8.55 & 9.19 & 9.24 & 13.76 & 13.71 & 10.06 & 16.67 \\
\hline $\mathrm{MnO}$ & 0.23 & 0.42 & 0.26 & 0.15 & 0.20 & 0.52 & 0.50 & 0.22 & 0.72 \\
\hline $\mathrm{MgO}$ & 13.91 & 15.17 & 15.59 & 17.12 & 15.49 & 12.68 & 13.97 & 14.24 & 14.84 \\
\hline $\mathrm{CaO}$ & 18.56 & 17.59 & 19.94 & 19.38 & 19.98 & 18.67 & 17.57 & 20.31 & 14.01 \\
\hline $\mathrm{Na}_{2} \mathrm{O}$ & 0.59 & 0.21 & nd & 0.25 & 0.26 & 0.26 & 0.16 & 0.24 & 0.12 \\
\hline $\mathrm{Cr}_{2} \mathrm{O}_{3}$ & 0.03 & nd & 0.17 & 0.58 & 0.60 & 0.17 & 0.24 & nd & 0.03 \\
\hline Total & 100.92 & 100.50 & 98.48 & 101.90 & 100.78 & 100.39 & 99.91 & 99.63 & 99.80 \\
\hline \multicolumn{10}{|c|}{ Ideal mineral proportions } \\
\hline Wo & 39.12 & 36.76 & 41.28 & 38.48 & 40.99 & 39.68 & 36.83 & 42.33 & 29.40 \\
\hline En & 40.78 & 44.11 & 44.90 & 47.28 & 44.21 & 37.49 & 40.73 & 41.30 & 43.31 \\
\hline Fs & 20.10 & 19.13 & 13.81 & 14.24 & 14.80 & 22.83 & 22.44 & 16.36 & 27.29 \\
\hline \multicolumn{10}{|c|}{ Cations in formula } \\
\hline $\mathrm{Si}$ & 1.88 & 1.93 & 1.94 & 1.92 & 1.92 & 1.86 & 1.95 & 1.90 & 1.95 \\
\hline $\mathrm{Al}$ & 0.19 & 0.13 & 0.10 & 0.10 & 0.12 & 0.19 & 0.08 & 0.15 & 0.07 \\
\hline $\mathrm{Ti}$ & 0.00 & 0.00 & 0.00 & 0.00 & 0.00 & 0.03 & 0.00 & 0.00 & 0.00 \\
\hline $\mathrm{Fe}$ & 0.38 & 0.36 & 0.27 & 0.28 & 0.29 & 0.44 & 0.43 & 0.32 & 0.53 \\
\hline $\mathrm{Mn}$ & 0.00 & 0.00 & 0.00 & 0.00 & 0.00 & 0.00 & 0.00 & 0.00 & 0.00 \\
\hline $\mathrm{Mg}$ & 0.77 & 0.84 & 0.87 & 0.93 & 0.85 & 0.72 & 0.79 & 0.80 & 0.84 \\
\hline $\mathrm{Ca}$ & 0.74 & 0.70 & 0.80 & 0.76 & 0.79 & 0.76 & 0.71 & 0.82 & 0.57 \\
\hline $\mathrm{Na}$ & 0.04 & 0.00 & 0.00 & 0.00 & 0.00 & 0.00 & 0.00 & 0.00 & 0.00 \\
\hline $\mathrm{Cr}$ & 0.00 & 0.00 & 0.00 & 0.00 & 0.00 & 0.00 & 0.00 & 0.00 & 0.00 \\
\hline
\end{tabular}

$125-781 \mathrm{~A}-10 \mathrm{R}-3,17-21 \mathrm{~cm}$

\begin{tabular}{lcccrrrr}
$\begin{array}{l}\text { Grain } \\
\text { type }\end{array}$ & Microphenocryst & Microphenocryst & $\begin{array}{c}4 \\
\text { Rim }\end{array}$ & $\begin{array}{c}4 \\
\text { Core }\end{array}$ & $\begin{array}{c}7 \\
\text { Rim }\end{array}$ & $\begin{array}{c}7 \\
\text { Core }\end{array}$ \\
\hline $\mathrm{SiO}_{2}$ & 50.44 & 50.50 & 51.59 & 51.11 & 51.51 & 52.20 \\
$\mathrm{Al}_{2} \mathrm{O}_{3}$ & 1.09 & 2.43 & 3.07 & 2.11 & 2.92 & 2.19 & 0.33 \\
$\mathrm{TiO}_{2}$ & 0.31 & 0.36 & 0.26 & 0.38 & 0.36 & 8.93 \\
$\mathrm{FeO}$ & 22.35 & 10.16 & 6.57 & 11.68 & 8.96 & 0.27 \\
$\mathrm{MnO}$ & 0.88 & 0.39 & 0.24 & 0.41 & 0.31 & 15.79 \\
$\mathrm{MgO}$ & 10.47 & 15.36 & 15.64 & 15.83 & 15.39 & 19.79 \\
$\mathrm{CaO}$ & 14.47 & 18.95 & 21.63 & 17.00 & 19.62 & 0.24 \\
$\mathrm{Na}_{2} \mathrm{O}$ & 0.15 & nd & nd & 0.47 & 0.24 & nd \\
$\mathrm{Cr}_{2} \mathrm{O}_{3}$ & nd & nd & nd & nd & 0.32 & nd \\
$\mathrm{Total}^{100.16}$ & nd & 98.15 & 99.00 & 98.99 & 99.63 & 99.74
\end{tabular}

Ideal mineral proportions

$\begin{array}{lllllll}\text { Wo } & 31.14 & 39.29 & 44.59 & 35.32 & 40.85 & 40.61 \\ \text { En } & 31.33 & 44.28 & 44.85 & 45.75 & 44.59 & 45.09 \\ \text { Fs } & 37.53 & 16.44 & 10.56 & 18.93 & 14.55 & 14.30\end{array}$

Cations in formula

$\begin{array}{lllllll}\mathrm{Si} & 1.97 & 1.92 & 1.92 & 1.93 & 1.92 & 1.94 \\ \mathrm{Al} & 0.05 & 0.11 & 0.13 & 0.09 & 0.13 & 0.10 \\ \mathrm{Ti} & 0.00 & 0.00 & 0.00 & 0.00 & 0.00 & 0.00 \\ \mathrm{Fe} & 0.73 & 0.32 & 0.20 & 0.37 & 0.28 & 0.28 \\ \mathrm{Mn} & 0.03 & 0.00 & 0.00 & 0.00 & 0.00 & 0.00\end{array}$


Table 4 (continued).

\begin{tabular}{|c|c|c|c|c|c|c|}
\hline $\begin{array}{l}\text { Grain } \\
\text { type }\end{array}$ & Microphenocryst & Microphenocryst & $\begin{array}{c}4 \\
\text { Rim }\end{array}$ & $\begin{array}{c}4 \\
\text { Core }\end{array}$ & $\begin{array}{c}7 \\
\text { Rim }\end{array}$ & $\begin{array}{c}7 \\
\text { Core }\end{array}$ \\
\hline Mg & 0.61 & 0.87 & 0.87 & 0.89 & 0.85 & 0.87 \\
\hline $\mathrm{Ca}$ & 0.60 & 0.77 & 0.86 & 0.69 & 0.78 & 0.79 \\
\hline $\mathrm{Na}$ & 0.00 & 0.00 & 0.00 & 0.03 & 0.00 & 0.00 \\
\hline $\mathrm{Cr}$ & 0.00 & 0.00 & 0.00 & 0.00 & 0.00 & 0.00 \\
\hline
\end{tabular}

Olivine

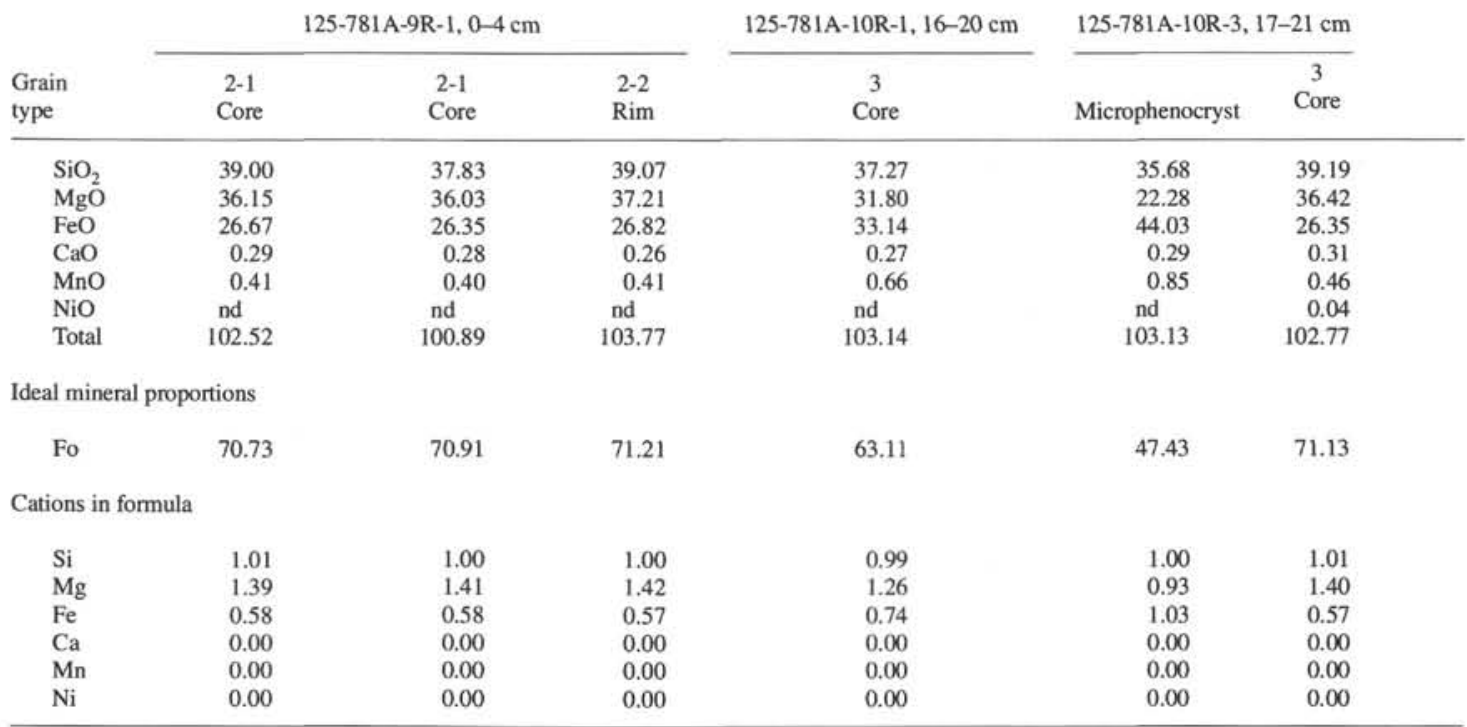

Titanomagnetite

\begin{tabular}{lrcc} 
& $\begin{array}{c}125-781 \mathrm{~A}- \\
9 \mathrm{R}-1, \\
0-4 \mathrm{~cm}\end{array}$ & $\begin{array}{c}125-781 \mathrm{~A}- \\
10 \mathrm{R}-1, \\
16-20 \mathrm{~cm}\end{array}$ & $\begin{array}{c}125-781 \mathrm{~A}- \\
10 \mathrm{R}-3, \\
17-21 \mathrm{~cm}\end{array}$ \\
\hline $\mathrm{FeO}$ & 76.81 & 81.20 & 78.08 \\
$\mathrm{TiO}_{2}$ & 10.40 & 10.73 & 15.10 \\
$\mathrm{MnO}$ & 0.54 & 0.40 & 0.60 \\
$\mathrm{MgO}$ & 1.17 & 3.37 & 1.84 \\
$\mathrm{SiO}_{2}$ & 1.14 & 0.11 & 0.08 \\
$\mathrm{Al}_{2} \mathrm{O}_{3}$ & 4.31 & 4.06 & 2.46 \\
$\mathrm{Cr}_{2} \mathrm{O}_{3}$ & 0.48 & nd & 0.12 \\
$\mathrm{CaO}$ & 0.20 & 0.03 & 0.04 \\
$\mathrm{Total}$ & 95.05 & 99.90 & 98.32
\end{tabular}

Note: Analyzed with a Cameca microprobe, the University of Hawaii, by L. E. Johnson. The grain number identifies single grain from which core and rim values were obtained. $\mathrm{nd}=$ none detected. All iron as FeO.

\section{Geochemistry}

The abundances of the major elements in the Site 781 lavas are similar to but not exactly like those typically found in Mariana Island Arc tholeiite (IAT) basalts (Stern et al., 1989; Lin et al., 1989) and are typical of IAT basalts. Samples from Site 781 are classified as basalt and plot within the low- $\mathrm{K}$ tholeiite field on an $\mathrm{SiO}_{2}-\mathrm{K}_{2} \mathrm{O}$ classification diagram (Fig. 7; after Peccerillo and Taylor, 1976). The samples show a moderate degree of iron enrichment and plot in the tholeiite field on an AFM diagram (Fig. 8; after Irvine and Baragar, 1971). Basaltic abundances of $\mathrm{SiO}_{2}(49.09-50.73 \mathrm{wt} \%)$, high $\mathrm{Al}_{2} \mathrm{O}_{3}(17.28-$ $18.17 \mathrm{wt} \%)$, and high $\mathrm{Fe}_{2} \mathrm{O}_{3} *\left(11.93-12.73 \mathrm{wt} \% ; \mathrm{Fe}_{2} \mathrm{O}_{3} *=\right.$ total iron calculated as $\mathrm{Fe}_{2} \mathrm{O}_{3}$ ) coupled with low $\mathrm{MgO}(4.21-4.56 \mathrm{wt} \%)$ are a common characteristic of the IAT series. The basalt chemistry more closely resembles the lower potassium tholeiitic lavas of Guguan, Asuncion, and the submarine volcanoes of the southern Mariana arc than the higher potassium, calc-alkaline lavas of Agrigan and Pagan
(Dixon and Batiza, 1979; Stern et al., 1989; Woodhead, 1988; Lin et al., 1989; Figs. 7 and 8 ) or the shoshonitic and high-K, calc-alkaline lavas in the seamount province of the northern Mariana Island Arc (Bloomer et al., 1989).

Compositional variations within the recovered core samples are small. Positive covariations in $\mathrm{CaO}$ and $\mathrm{Al}_{2} \mathrm{O}_{3}$ that are inversely correlated with covariations in $\mathrm{MgO}$ and $\mathrm{Fe}_{2} \mathrm{O}_{3} *$ can be explained simply by variation in the proportion of phenocrysts of plagioclase feldspar or mafic phases; a small part of the variation in potassium can be related to alteration. Overall, however, the data are consistent with a single, chemically homogeneous intrusion, and we find little evidence for internal fractionation.

Compatible elements ( $\mathrm{Sr}, \mathrm{V}, \mathrm{Cr}$, and $\mathrm{Ni}$ ) show a similar pattern to the major elements with small variations that probably relate to the relative proportion of plagioclase and mafic phenocrysts. As in the case of $\mathrm{K}$, the mobile elements $\mathrm{Rb}, \mathrm{Ba}$, and $\mathrm{Cu}$ show small variations that may be related to alteration. REE patterns from three samples 


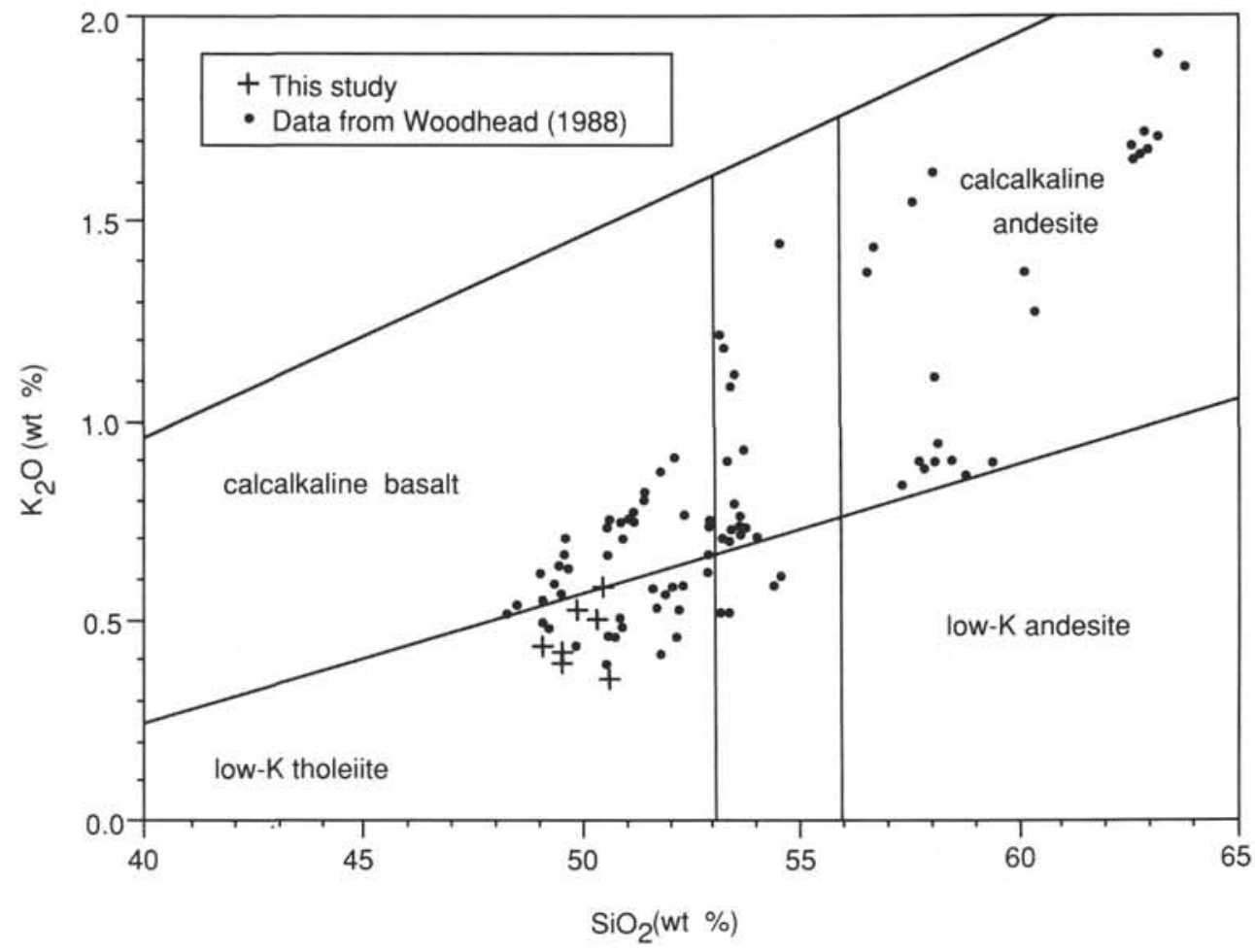

Figure 6. Pyroxene quadrilateral. Each point represents between two and six analyses of individual crystals. No zoning between cores and rims or crystal types was observed. Fields are from Poldervaart and Hess (1951).

representing the top, center, and base of the recovered basalt are essentially flat at about 10 times chondrite (Fig. 9). The patterns show a slight light REE (LREE) and heavy REE (HREE) depletion that gives a "humped" effect. The shallowest sample (125-781A-9R-1, $69-71 \mathrm{~cm}$ ) has slightly lower abundances than the deeper samples and a more distinct HREE depletion. The patterns fall at the lower end of the range of active Mariana arc lava patterns (Fig. 9; Stern et al., 1989), which vary from flat to LREE enriched; the latter, in particular, have distinct negative $\mathrm{Ce}$ anomalies that are not apparent in the Site 781 basalt.

The incompatible trace element characteristics of the basalts can be portrayed using multielement plots, normalized to normal MORB (N-MORB; Pearce, 1983). On such a diagram, magmas derived from a depleted convecting mantle source similar to a MORB source will show a flat pattern. Magmas derived from the mantle overlying a subducting slab typically give patterns that are depleted in the incompatible high-field-strength (HFS) elements (Y, Ti, Zr, and the middleheavy REEs) and are selectively enriched in the large-ion lithophile (LIL) elements ( $\mathrm{Sr}, \mathrm{K}, \mathrm{Rb}, \mathrm{Ba}$, and usually also LREEs and $\mathrm{Th}$ ) that are derived from the subducted oceanic lithosphere and its sediment cover through dehydration and partial melting. The type of enrichment pattern will also vary from arc to arc according to the nature of the subducted material and the thermal and geodynamic parameters of the subduction system (Pearce, 1983). The MORB normalizing values used in Figure 10 are taken with slight modifications from the compilation by Sun and McDonough (1989), and the ordering of the elements (with the exception of $\mathrm{Sr}$ and $\mathrm{K}$ ) is based on the relative incompatibility (increasing from left to right) during lherzolite melting and is taken from Pearce (1983).

Patterns from four Mariana arc volcanoes, the forearc tholeiitic suite from Deep Sea Drilling Project (DSDP) Site 459, and the Site 781 rocks show selective enrichments (relative to N-MORBs) in all LIL elements from $\mathrm{Sr}$ through $\mathrm{Th}$ and relatively flat, though slightly depleted, patterns for the HFS elements (Hf-Yb; Fig. 10). Agrigan Island and Fukujin Seamount are calc-alkaline volcanoes in the central and northern Mariana arc, respectively (Bloomer et al., 1989). Esmerelda Bank and Ruby Seamount are submarine volcanoes in the southern Mariana arc that erupt lavas with some tholeiitic characteristics (Stern et al., 1989).

Abundances of $\mathrm{Sr}, \mathrm{K}$, and $\mathrm{Rb}$ are all lower for the basalt at Site 781 than for the arc volcanoes, although the $\mathrm{Ba}$ content is in the range of values for the arc volcanoes. The Site 781 lavas most closely resemble the lavas from Ruby Seamount, although $\mathrm{Ba}$ is slightly enriched and P slightly depleted in the Site 781 lavas relative to those of Ruby. Th is depleted and Ta and Nb enriched in the Site 781 basalt relative to the Agrigan and Pagan lavas; however, data for Th, Ta, and $\mathrm{Nb}$ are unavailable for other arc volcanoes. La in the Site 781 basalt is depleted relative to that of Fukujin and Agrigan lavas but the same as in samples from Ruby Seamount and the Site 458 tholeiites. The Site 781 lavas are slightly depleted in HFS elements ( $\mathrm{Hf}-\mathrm{Yb}$ ) relative to many of the arc volcanoes (Fig. 10), but are similar to those from Ruby Seamount. The Site 458 samples show similar patterns to the arc volcanoes although they are more distinctly depleted in Ti, P, and $\mathrm{Ba}$. Although the enrichment in the mobile LIL elements in the samples from Site 458 may be caused by alteration, the enrichment for the Site 781 basalt and the arc volcanoes must be a primary feature.

The enrichment of the mobile elements $(\mathrm{Sr}, \mathrm{K}, \mathrm{Rb}$, and $\mathrm{Ba})$, relative to $\mathrm{N}-\mathrm{MORB}$, suggests that the magma source was in the mantle overlying, not beneath, the subducting plate. Because mobile elements are released from subducted sediment and basaltic crust at subsolidus temperatures during prograde dehydration of the subducted slab, the source of these mobile elements in arc lavas must be at depths less than $50 \mathrm{~km}$ and is probably within the upper part of the subducted slab. Th and the LREEs are mobilized only when temperatures are higher, when sediment melting can take place. Thus, they would be expected to be released from the subducted slab at greater depths. The higher Th and La content in Agrigan lavas than in the Site 781 basalt may reflect a higher sediment contribution to the Agrigan source. The apparently lower sediment contribution to the Site 781 lavas may indicate a shallower source, perhaps trenchward of the 


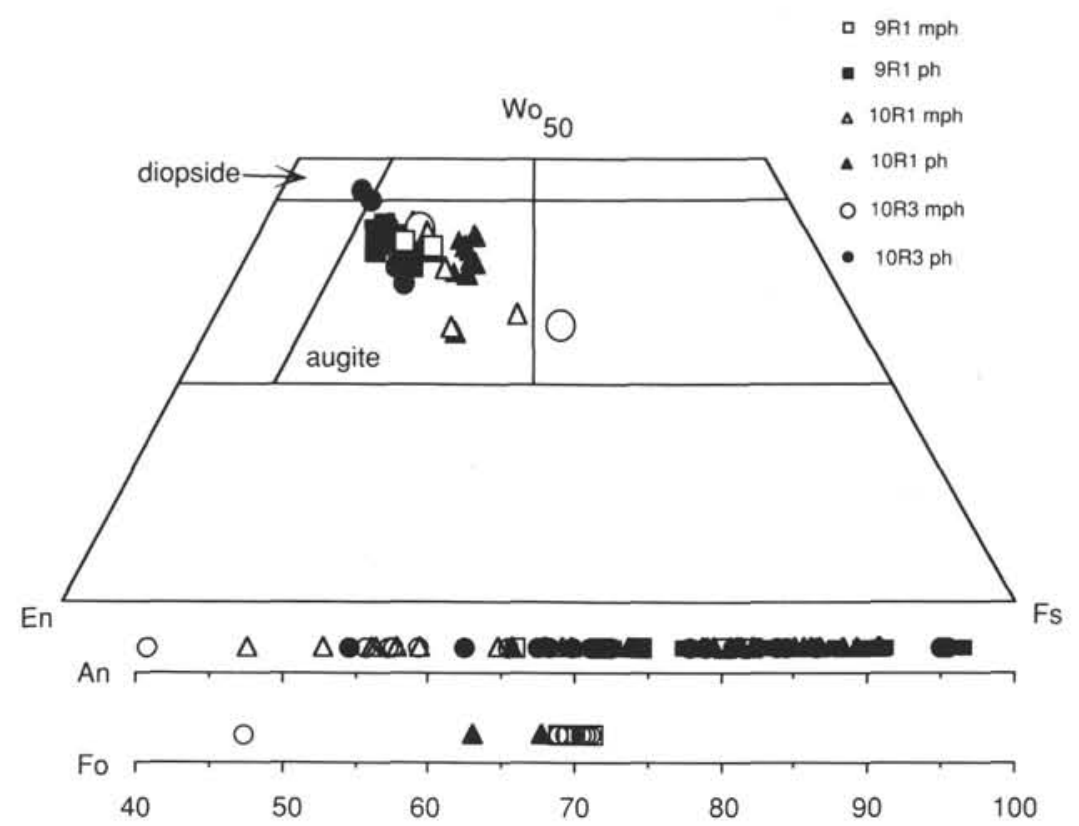

Figure 7. Classification of the basalt sill at Site 781, based on potassium-silica covariation. Fields are from Peccerillo and Taylor (1976). Dots are analyses of active Mariana arc volcanic features (Woodhead, 1988).

source for Agrigan and Fukujin. The amounts of the HFS elements $(\mathrm{Y}, \mathrm{Zr}$, and $\mathrm{Nb}$ ) in the Site 781 basalts are comparable to those of volcanic rocks from the active arc. This suggests a like degree of melting and the involvement of similar mantle for the origin of the sill as for the volcanoes in the active arc. Models for small degrees of hydrous melting of the shallower, more harzburgitic, lithosphere of the mantle are not favored, as they should produce more boninitic compositions with major depletions in many HFS elements (e.g., Hickey-Vargas and Reagan, 1987). The slightly lower abundances of the HFS elements in the dredged and previously drilled forearc sites

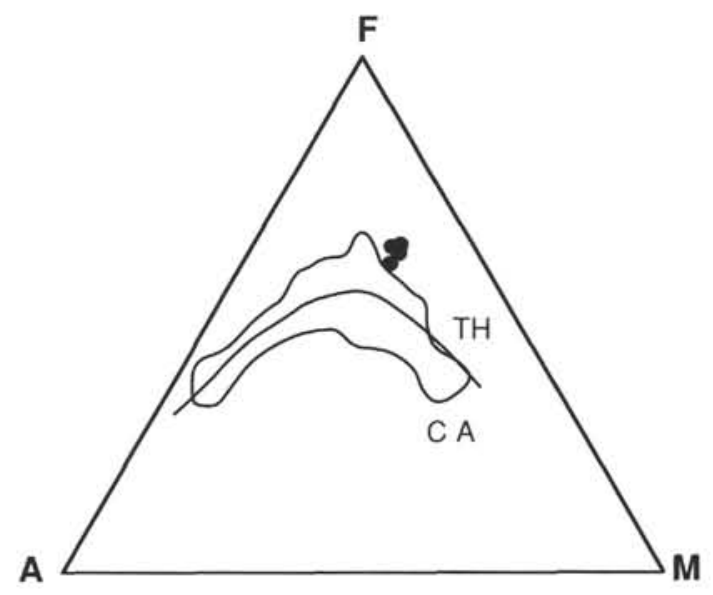

- Sité 781

Figure 8. Classification of the basalt sill on the basis of $\mathrm{Fe}$ enrichment. The dividing line is from Irvine and Baragar (1971). Dots represent analyses of active Mariana arc volcanic features (Woodhead, 1988). suggest a slightly lower proportion of melting or a more depleted source than that for Site 781 .

\section{Isotope Systematics}

Figure 11 compares $\mathrm{Sr}$ and $\mathrm{Nd}$ isotope ratios for the Site 781 basalts with isotope ratios for lavas from the active Mariana arc (Woodhead, 1989), Mariana Trough (Volpe et al., 1987), and Eocene to Oligocene Mariana forearc basement (Hickey-Vargas, 1989; Hickey-Vargas and Reagan, 1987). Active arc rocks have higher Sr and lower Nd ratios than rocks from the Mariana Trough. The basalt from Site 781 plots at the high end of the active arc field in terms of $\mathrm{Nd}$ isotope ratios, although its $\mathrm{Sr}$ isotope ratio is comparable.

In a $\mathrm{Pb}$ isotope diagram (Fig. 12), the lavas from the active Mariana arc plot off the Northern Hemisphere Reference Line (NHRL) (the line containing MORB and Northern Hemisphere oceanic islands) of Hart (1984) toward pelagic sediments (or a mixture of pelagic and volcanogenic sediments). The Eocene to Oligocene forearc basement (Meijer, 1976, 1983) plots along or near the NHRL. The Site 781 sample plots in the center of the active arc field.

\section{DISCUSSION}

Sedimentary strata recovered above and below the basalt have a biostratigraphic age of late Pliocene (nannofossil Subzone CN12b). The mineralogy, texture, and chemistry of the Site 781 basalt are remarkably constant throughout the unit. The compositional homogeneity and the absence of any distinct internal flow boundaries suggest that basalt formation was a single intrusive event. The contact between the basalt and upper sedimentary strata is a narrow glassy margin with no pillow structures or breccia. These observations, along with the $\mathrm{K}-\mathrm{Ar}$ age of $1.7 \mathrm{Ma}$, indicate that the basalt layer was injected in situ as a sill. The magma was probably intruded from the fault zone bounding the graben and then was quenched against the overlying sediment. Petrographic and geochemical evidence for interaction of the basalt with the overlying sediment is absent; however, low recovery $(28 \%-55 \%)$ and a gap of $29 \mathrm{~m}$ following the last recovered 


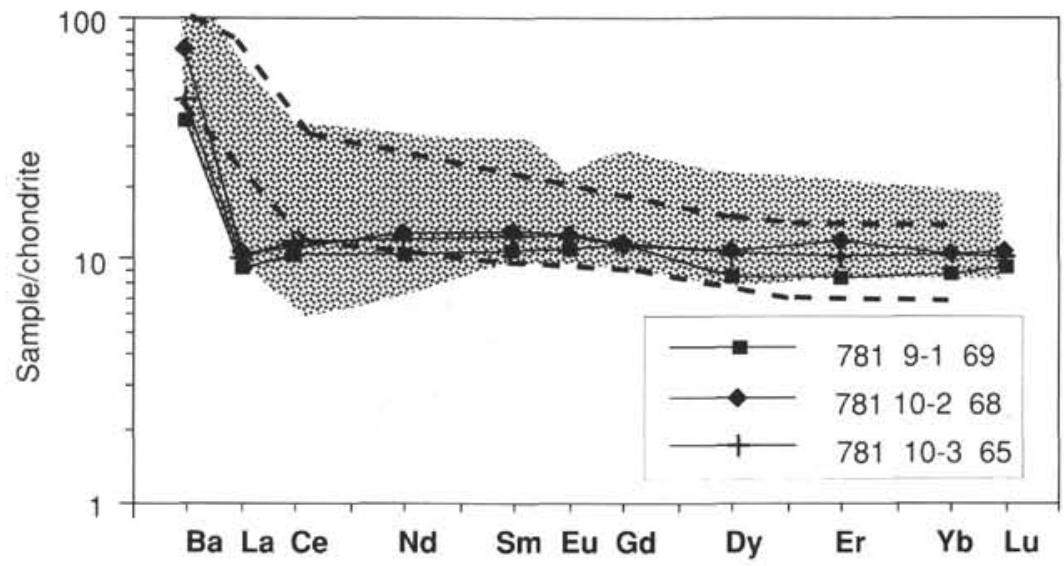

Figure 9. Chondrite-normalized REE patterns. The relatively flat pattern with a small "sway" in the middle REEs is characteristic of Mariana arc lavas. The fields are from the Mariana aerial (stippled) and submarine (dashed outline) volcanoes of Stern et al. (1989).

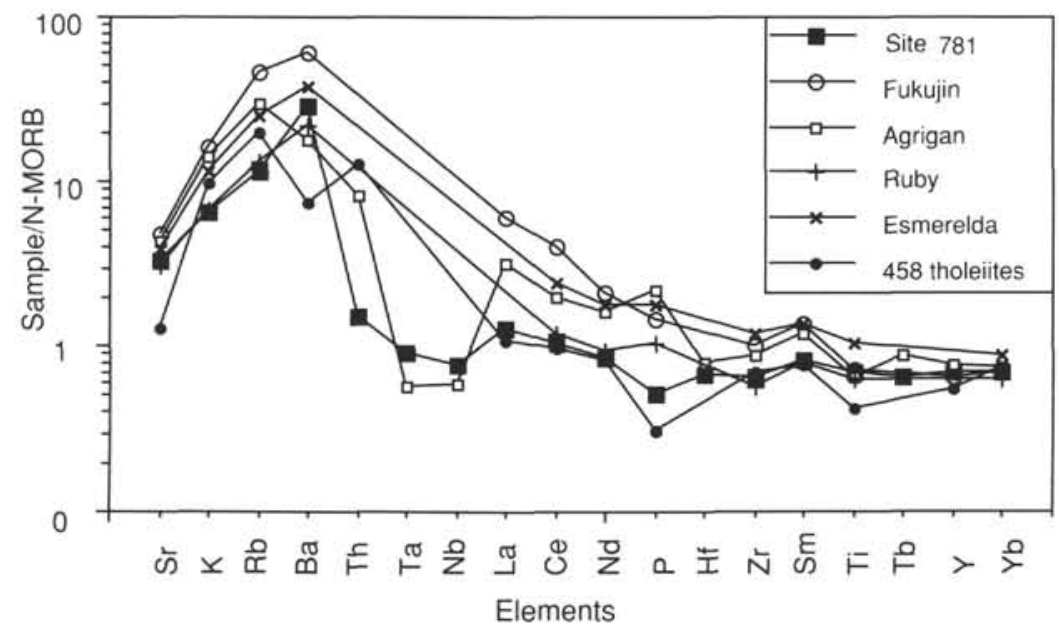

Figure 10. MORB-normalized incompatible trace element patterns for Site 781 basalt in comparison with a nearby, active subaerial volcano, Agrigan Island (J. A. Pearce, unpubl. ICP-MS data), DSDP Hole 458 (Mattey et al., 1980; Wood et al., 1982), submarine volcanoes Ruby and Esmerelda in the southern Mariana arc (Stern et al., 1989), and the submarine volcano Fukujin in the northern Mariana arc (Bloomer et al., 1989). Normalizing values are from Sun and McDonough (1989) and Pearce (1983). Data for the Site 781 samples are given in Tables 1 through 3.

rock at 92 mbsf (Fryer, Pearce, Stokking, et al., 1990) may have prevented the identification of flow contacts. This basalt is the youngest in-situ igneous layer reported in the Izu-Bonin and Mariana forearcs (Marlow et al., 1988), and its genesis is important for understanding the emplacement of volcanic rocks in forearc settings.

Several models for the generation of igneous rocks in forearc settings have been discussed by Hussong and Uyeda (1982b), Kobayashi (1983a, 1983b), and Marlow et al. (1988). However, as we shall see in the following discussion, none of the models offers a satisfactory explanation for the generation of basalt at Site 781 .

An early model for generating forearc volcanic rocks shown in Figure 13A (from Hussong and Uyeda, 1981b) involves a vertical subarc magma source that formed when the subducting slab was seaward of its present location. The model implies tectonic erosion of the older forearc, so that the Site 781 basalt would now be in the forearc of a younger arc to the west. The young age of the Site 781 basalt (1.7 Ma) precludes such a model.
Another model proposed for forming forearc volcanic rocks is shown in Figure 13B. The forearc magma source here is from mantle beneath fractured oceanic crust. The resulting magmas should be MORB-like from such a mantle source. The magmas from Site 781 are not MORB-like but are tholeiitic and characteristic of an island arc source, not an oceanic mantle source.

Yet another model involves the generation of magma from a subarc source that is diverted either as a lateral sill or inclined dike that eventually reaches the middle of the forearc (Fig. 13C). However, Site 781 is $100 \mathrm{~km}$ from the island arc and the sill or dike would have to travel at least this distance through cold crust and sediment to reach the middle of the forearc; such a supposition is difficult to accept.

The simplest model for the emplacement of the basalt at Site 781 involves a source beneath the site (Fig. 13D). Such a source would presumably involve the melting of oceanic crust and sediment and the mantle wedge above the subducting slab to generate a tholeiitic basalt with the chemistry described earlier (Fig. 14). A vertical feeder system 

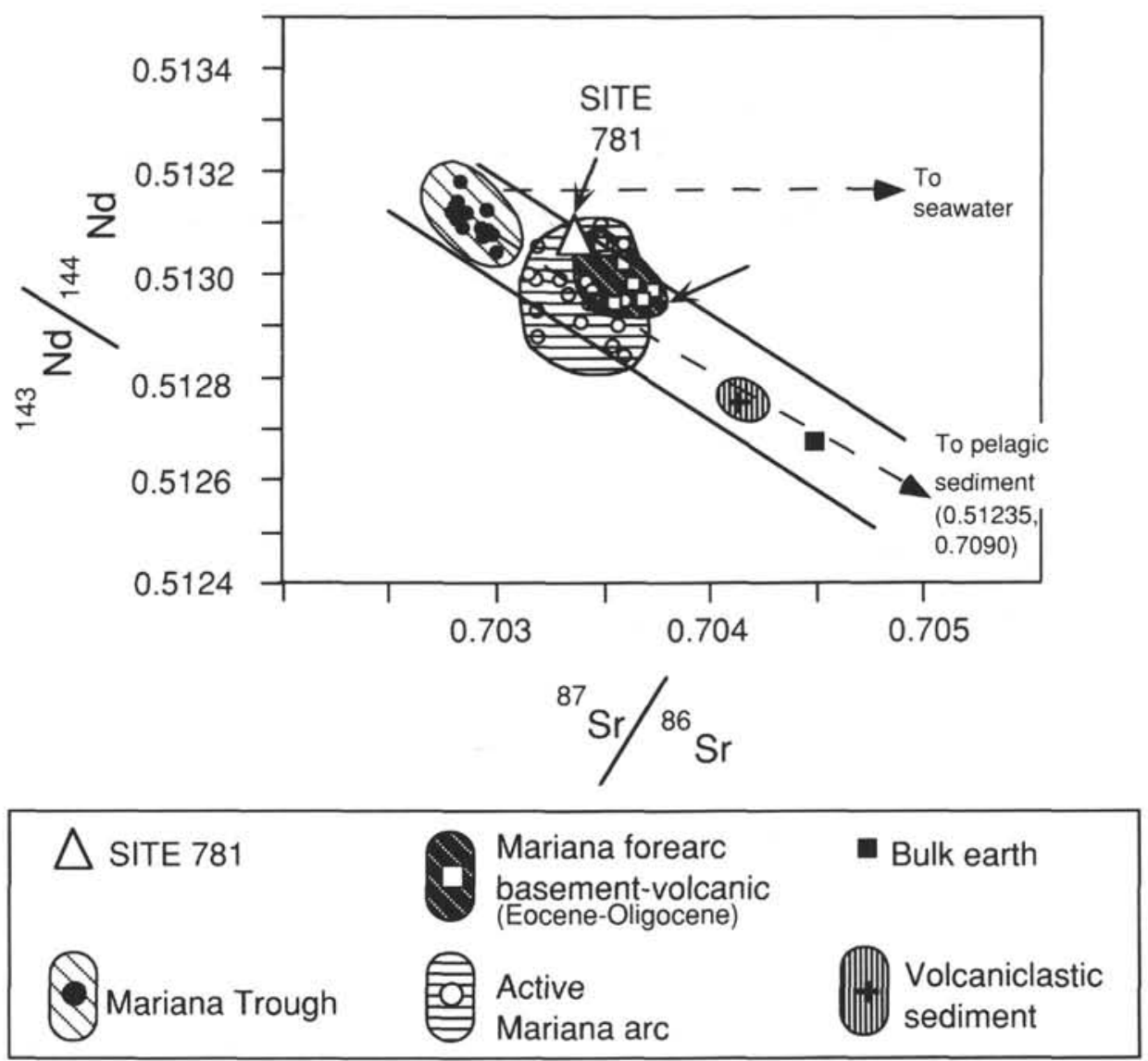

Figure 11. Sr-Nd isotope covariation diagram for the basalt sill at Site 781 compared with Eocene-Oligocene forearc boninitic-tholeitic lavas and lavas from the Mariana Trough and active Mariana arc.

directly under the forearc would require magma production where the depth to the subducted Pacific plate is only about 20 or $30 \mathrm{~km}$ deep (Hussong and Uyeda, 1981b; Eguchi, 1984). This region of the subducted slab beneath the forearc is probably too shallow to have generated sufficient heat to melt the overlying mantle wedge, unless there was sufficient hydration of the region by extensional fracturing. If the magma source is directly beneath Site 781 , then thermal models of this forearc will undoubtedly have to be revised to allow for shallow melting. Without deep penetration seismic-reflection data, we cannot confirm any particular model.

\section{CONCLUSIONS}

Seismic-reflection surveys revealed a small horst and graben structure in the midregion of the Mariana forearc at $19^{\circ} 30 \mathrm{~N}$ and near Conical Seamount, a serpentine mud volcano. A high-amplitude reflection occurs at about 70 mbsf within the horst and can be seen on both sides of the fault bounding the graben. Drilling at Site 781 intersected 13 to $25 \mathrm{~m}$ of a reversely polarized Pleistocene (1.7 Ma) tholeiitic basalt sill in normally polarized late Pliocene age (2.5 Ma) sediment. The basalt sill is chemically and petrographically homogeneous and appears to be a single cooling unit.

Geochemical analysis indicates that the basalt sill is an island arc tholeiite similar to lavas from the active Mariana arc volcanoes. Multielement analysis of the basalt indicates a magma source from the mantle above the subduction zone. Further drilling and seismicreflection surveys are necessary to delineate the magma conduits that fed the sill at Site 781 .

\section{ACKNOWLEDGMENTS}

The authors thank Alan K. Cooper, Randolph A. Koski, T. H. Dixon, Sherman H. Bloomer, and Robert J. Stern for their thoughtful and helpful reviews of this manuscript. LEJ thanks D. Sims and J. Glasser for XRF analyses and thin-section preparation, respectively, aboard JOIDES Resolution; T. Hulsebosch for assisting with XRF and microprobe analyses at the University of Hawaii; and G. Eberhardt and C. Langmuir for assistance during REE analyses at Lamont-Doherty Geological Observatory. This research is part of LEJ's doctoral dissertation at the University of Hawaii. LEJ acknowledges USSAC for salary support during Leg 125 and for a post-cruise grant (TAMU Research Foundation P.O. numbers 20265 and 20352). JAP thanks Sorena Sorensen for her help in obtaining Mariana arc samples from the Smithsonian collection, Matthew Thirlwall and Gerry Ingram (RHBNC, London) for isotope facilities, and the Natural Environment Research Council (U.K.) for a research grant (GST/02/416).

\section{REFERENCES}

Bloomer, S. H., 1983. Distribution and origin of igneous rocks from the landward slopes of the Mariana Trench: implications for its structure and evolution. J. Geophys. Res., 88:7411-7428.

Bloomer, S. H., and Hawkins, J. W., 1983. Gabbroic and ultramafic rocks from the Mariana Trench: an island arc ophiolite. In Hayes, D. E. (Ed.), The Tectonic and Geologic Evolution of Southeast Asian Seas and Islands (Pt. 2). Am. Geophys. Union, Geophys. Monogr. Ser., 27:294-317.

, 1987. Petrology and geochemistry of boninite series volcanic rocks from the Mariana Trench. Contrib. Mineral. Petrol., 97:361-377. 

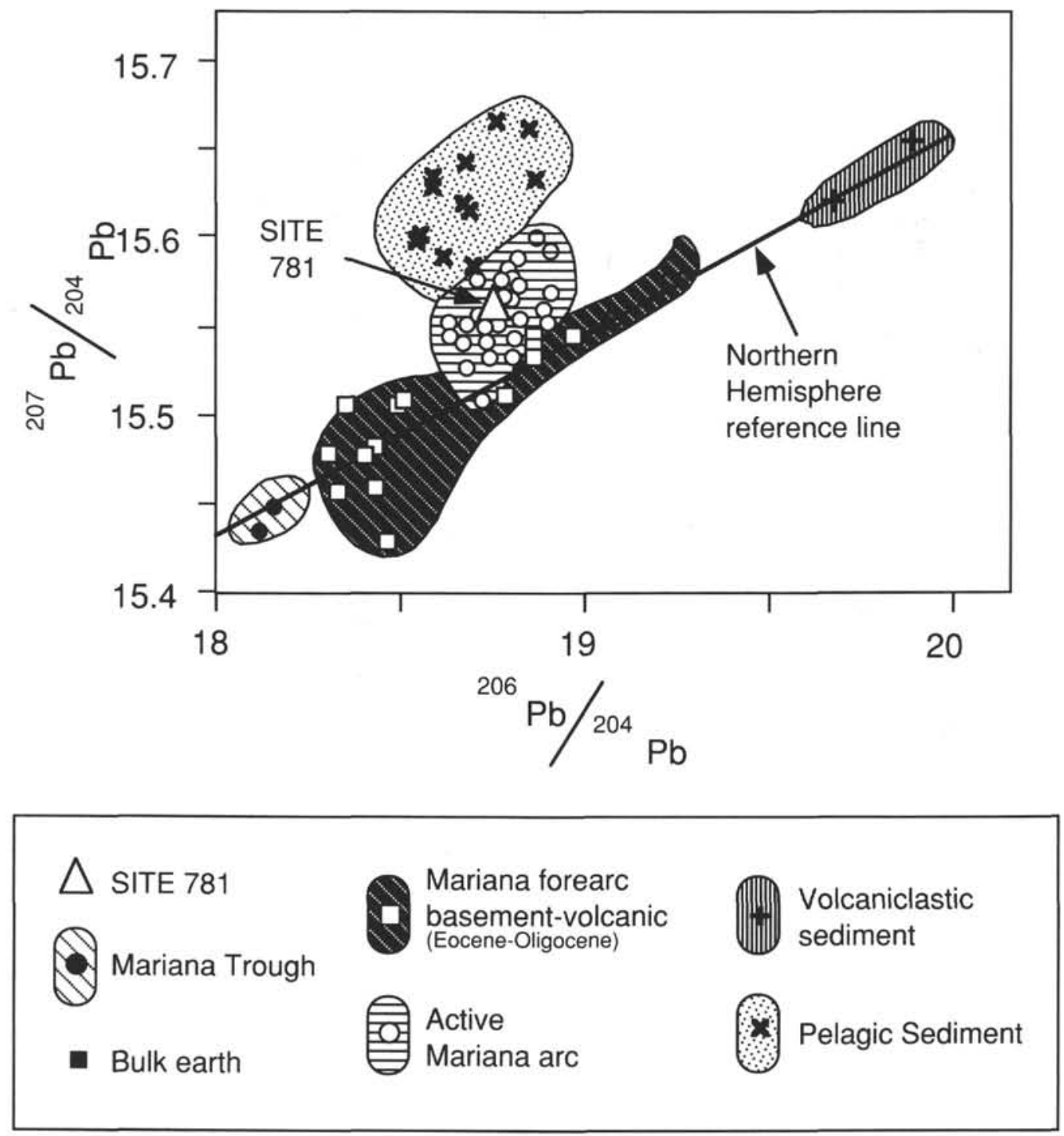

Figure 12. $\mathrm{Pb}$ isotope diagram for the basalt sill at Site 781 (triangle) compared with Eocene-Oligocene forearc boninitictholeiitic lavas and lavas from the Mariana Trough and active Mariana arc.

Bloomer, S. H., Stern, R. J., Fisk, E., and Geshwind, C. H., 1989. Shoshonitic volcanism in the northern Mariana Arc. 1. Mineralogic and major and trace element characteristics. J. Geophy. Res., 94:4469-4496.

Byerly, G. R., Melson, W. G., Newlen, J. A., and Jarosewhich, E., 1977. Abyssal basaltic glasses as indicators of magma compositions. Smithsonian Contrib. Earth Sci., 19:22-30.

Dixon, T. H., and Batiza, R., 1979. Petrology and chemistry of recent lavas in the northern Marianas: implications for the origin of island arc basalts. Contrib. Mineral. Petrol., 70:167-181.

Eguchi, T., 1984. Seismotectonics around the Mariana Trough. Tectonophysics, 102:33-52.

Fryer, P., Ambos, E. L., and Hussong, D. M., 1985. Origin and emplacement of Mariana forearc seamounts. Geology, 13:774-777.

Fryer, P., and Fryer, G. J., 1987. Origins of non-volcanic seamounts in a forearc environment. In Keating, B. H., Fryer, P., Batiza, R., and Boehlert, G. W. (Eds.), Seamounts, Islands and Atolls. Am. Geophys. Union, Geophys. Monogr. Ser., 43:61-69.

Fryer, P., Haggerty, J., Tilbrook, B., Sedwick, P., Johnson, L., Saboda, K., Newsom, S., Karig, D., Uyeda, S., and Ishii, T., 1987. Results of ALVIN studies of Mariana forearc serpentinite diapirism. Eos, 68:1534.
Fryer, P., Pearce, J. A., Stokking, L. B., et al., 1990. Proc. ODP, Init. Repts., 125: College Station, TX (Ocean Drilling Program).

Hart, S. R., 1984. A large-scale isotope anomaly in the Southern Hemisphere mantle. Nature, 300:753-757.

Hickey-Vargas, R., 1989. Boninites and tholeiites from DSDP Site 458, Mariana forearc. In Crawford, A. J. (Ed.), Boninites and Related Rocks: London (Unwin Hyman), 339-356.

Hickey-Vargas, R., and Reagan, M. K., 1987. Temporal variation of isotope and rare-earth element abundances in volcanic rocks from Guam: implications for the evolution of the Mariana arc. Contrib. Mineral. Petrol., 97:497-508.

Hilde, T.W.C., and Uyeda, S. (Eds.), 1983. Geodynamics of the Western Pacific-Indonesian Region. Am. Geophys. Union, Geodyn. Ser., 11.

Hilde, T.W.C., Uyeda, S., and Kroenke, L., 1977. Evolution of the western Pacific and its margin. Tectonophysics, 38:145-165.

Hussong, D. M., and Fryer, P., 1982. Structure and tectonics of the Mariana arc and fore-arc: drillsite selection surveys. In Hussong, D. M., and Uyeda, S., et al., Init. Repts. DSDP, 60: Washington (U.S. Govt. Printing Office), 33-44.

1985. Fore-Arc tectonics in the northern Mariana Arc. In Nasu, N. (Ed.), Formation of Active Ocean Margins: Tokyo (Terra Sci.), 273-290. 


\section{Models For Forearc Volcanism At Site 781}

A. Subarc source when subducting slab is seaward of present location (tectonic erosion of forearc) basalt is too young

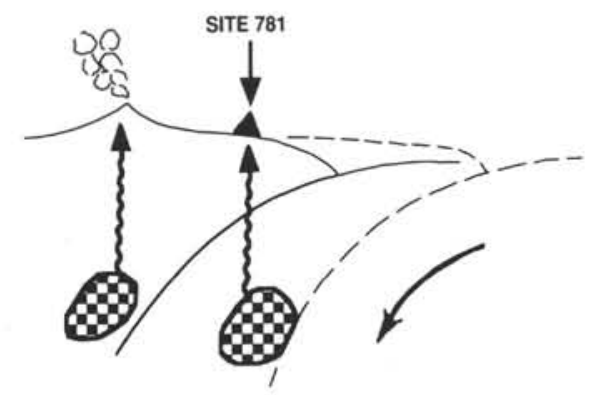

B. Source in fractured oceanic crust - basalt chemistry wrong

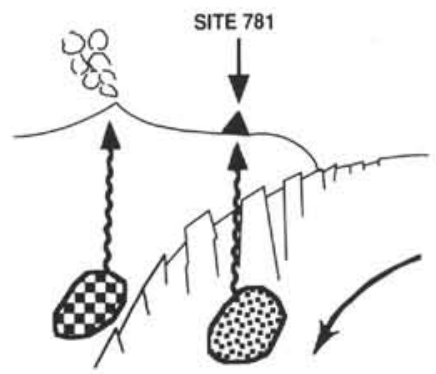

C. Subarc source and lateral sill injection into the forearc mechanically difficult

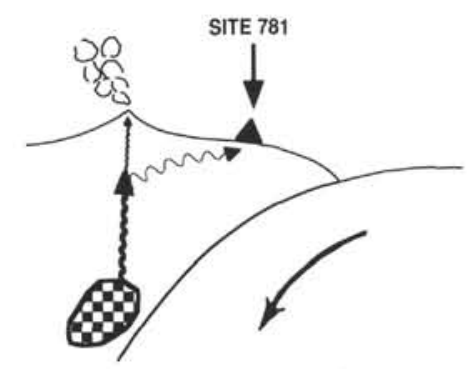

D. Simplest model vertical injection of magma from a source directly beneath Site 781

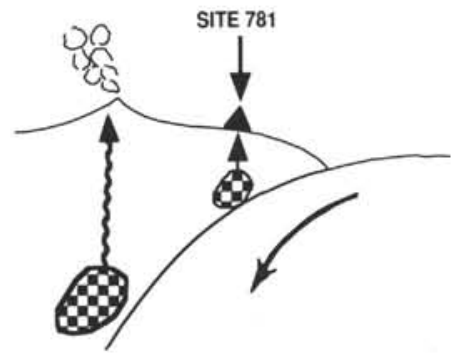

Figure 13. Schematic diagram showing models for forearc volcanism. A. An earlier, deep source (about $150-200 \mathrm{~km}$ or normal depths for island arc volcanoes). B. A magma source from within or below the fractured and subducting oceanic lithosphere. C. Magma transport along a nearly horizontal conduit from near the sources for the active volcanoes. D. Vertical injection from a source beneath Site 781. (Diagram adapted from Hussong and Uyeda, 1981b.) 


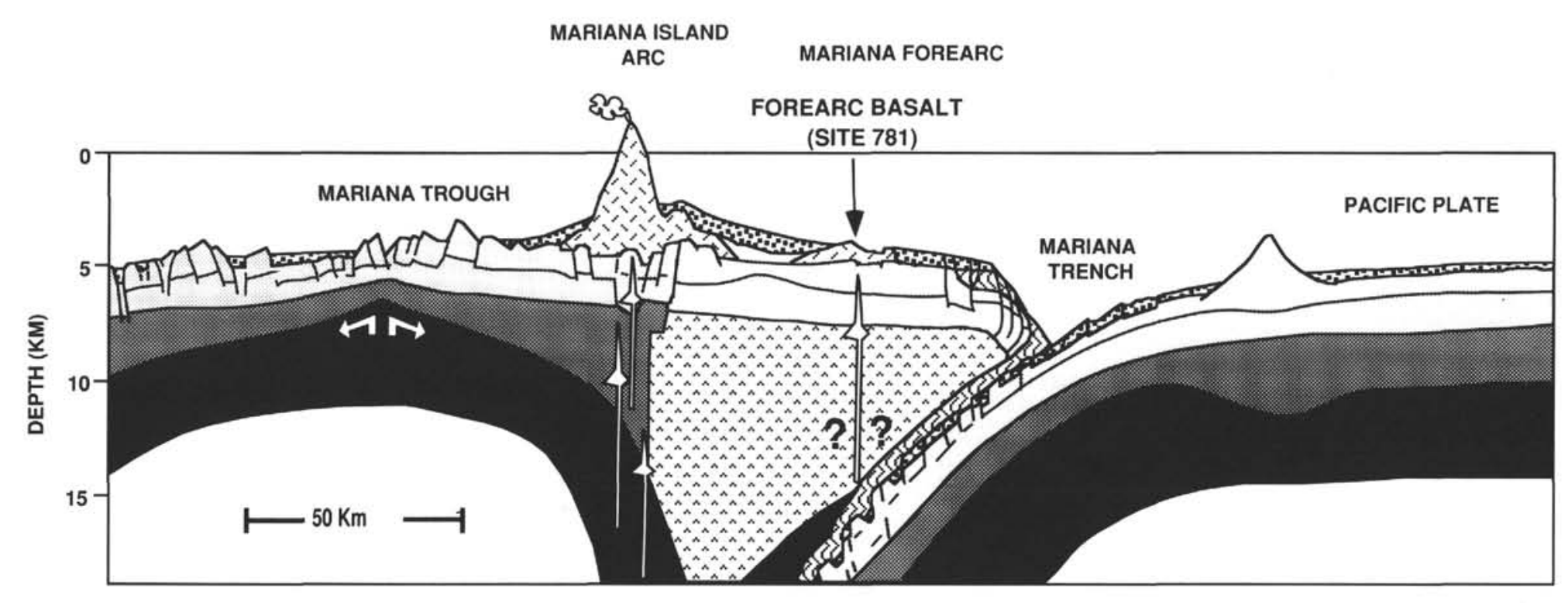

\section{EXPLANATION:}

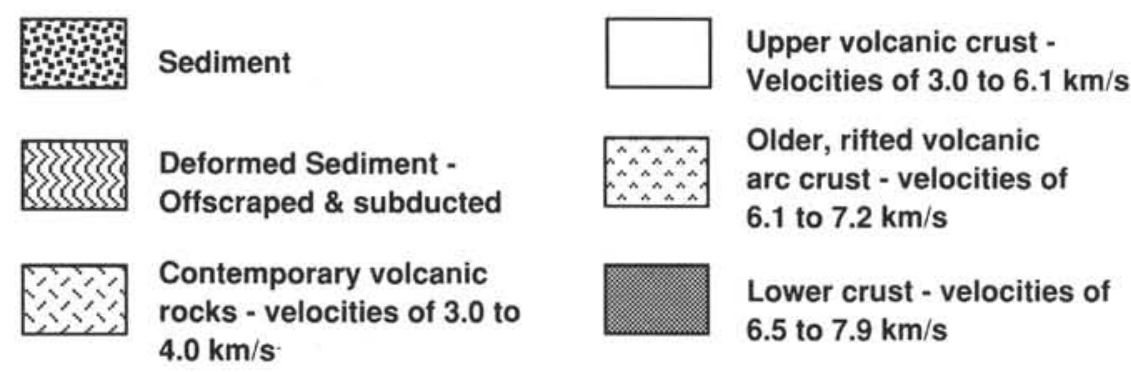

Figure 14. Cross section of the Mariana arc system, with Site 781 projected on the crustal section as adapted from Hussong and Uyeda (1981b), based on their seismic-refraction and reflection measurements. The basalt sill drilled at Site 781 is derived from shallow melting of the mantle wedge beneath Site 781 and above the subducting slab. 
Hussong, D. M., and Uyeda, S., 1982a. Mariana Arc and fore-arc background objectives. In Hussong, D. M., and Uyeda, S., et al., Init. Repts. DSDP, 60: Washington (U.S. Govt. Printing Office), 251-254.

$-1982 \mathrm{~b}$. Tectonic processes and the history of the Mariana Arc: a synthesis of the results of Deep Sea Drilling Project Leg 60. In Hussong, D. M., and Uyeda, S., et al., Init. Repts. DSDP, 60: Washington (U.S. Govt. Printing Office), 909-929.

Irvine, T. N., and Baragar, W. R., 1971. A guide to the chemical classification of the common igneous rocks. Can. J. Earth Sci., 8:523-545.

Johnson, L. E., and Fryer, P., 1990. The first evidence of MORB-like lavas from the outer Mariana forearc: geochemistry, petrography and tectonic implications. Earth Planet. Sci. Lett., 100:304-316.

Johnson, L. E., Fryer, P., Taylor, B., Silk, M., and Jones, D. L., in press. New evidence for crustal accretion in the outer Mariana forearc: Cretaceous radiolarian cherts and MORB-like lavas. Geology.

Karig, D. E., 1971. Structural history of the Mariana Island Arc system. Geol. Soc. Am. Bull., 82:323-344.

1975. Basin genesis in the Philippine Sea. In Karig, D. E., and Ingle, J. C., Jr., et al., Init. Repts. DSDP, 31: Washington (U.S. Govt. Printing Office), 857-879.

Karig, D. E., and Ranken, B., 1983. Marine geology of the forearc region, southern Mariana Trough. In Hayes, D. E. (Ed.), The Tectonic and Geologic Evolution of Southeast Asian Seas and Islands (Pt. 2). Am. Geophys. Union, Geophys. Monogr. Ser., 27:266-280.

Kobayashi, K., 1983a. Cycles of subduction and Cenozoic arc activity in the northwestern Pacific margin. In Hilde, T.W.C., and Uyeda, S. (Eds.), Geodynamics of the Western Pacific-Indonesian Region. Am. Geophys. Union, Geodyn. Ser., 11:287-301.

, 1983b. Fore-arc volcanism and cycles of subduction. In Shimozuru, D., and Yokoyama, I. (Eds.), Arc Volcanism: Physics and Tectonics: Tokyo (Terra Sci.), 153-163.

Lin, P.-N., Stern, R. J., and Bloomer, S. H., 1989. Shoshonitic volcanism in the northern Mariana arc 2: large-ion lithophile and rare earth element abundances evidence for the source of incompatible element enrichments in intraoceanic arcs. J. Geophys. Res., 94:4497-4514.

Marlow, M. S., Exon, N. F., and Tiffin, D. L., 1988. Widespread lava flows and sediment deformation in a forearc setting north of Manus Island Northern Papua New Guinea. In Marlow, M. S., Dadisman, S. V., and Exon, N. F. (Eds.), Geology and Offshore Resources of Pacific Island Arcs-New Ireland and Manus Region, Papua New Guinea. Circum-Pac. Counc. Energy Mineral Resour., Earth Sci. Ser., 9:221-237.

Marlow, M. S., Merrill, D. L., and Shipboard Scientific Party, 1990. Underway geophysics. In Fryer, P., Pearce, J. A., Stokking, L. B., et al., Proc. ODP, Init. Repts., 125: College Station, TX (Ocean Drilling Program), 41-67.

Mattey, D. P., Marsh, N. G., and Tarney, J., 1980. The geochemistry, mineralogy and petrology of basalts from the West Philippine and Parece Vela Basins and from the Palau-Kyushu and West Mariana Ridges, Deep Sea Drilling Project Leg 59. In Kroenke, L., and Scott, R., et al., Init. Repts. DSDP, 59: Washington (U.S. Govt. Printing Office), 753-797.

Meijer, A., 1976. $\mathrm{Pb}$ and Sr isotopic data bearing on the origin of volcanic rocks from the Mariana island-arc system. Geol. Soc. Am. Bull., 87:1358-1369. 1983. The origin of low-K rhyolites from the Mariana frontal arc. Contrib. Mineral. Petrol., 83:45-51.
Meijer, A., Anthony, E., and Reagan, M., 1982. Petrology of volcanic rocks from the fore-arc sites. In Hussong, D. M., and Uyeda, S., et al., Init. Repts. DSDP, 60: Washington (U.S. Govt. Printing Office), 709-729.

Mrozowski, C. L., Hayes, D. E., and Taylor, B., 1982. Multichannel seismic reflection surveys of Leg 60 sites. In Hussong, D. M., and Uyeda, S., et al., Init. Repts. DSDP, 60: Washington (U.S. Govt. Printing Office), 57-70.

Norrish, K., and Chappell, B., 1977. X-ray fluorescence spectrometry. In Zussman, J. (Ed.), Physical Methods in Determinative Mineralogy: New York (Academic Press), 201-272.

Norrish, K., and Hutton, J. T., 1969. An accurate X-ray spectrographic method for the analysis of a wide range of geological samples. Geochim. Cosmochim. Acta, 33:31-453.

Ogawa, Y., and Naka, J., 1984. Emplacement of ophiolitic rocks in forearc areas: examples from central Japan and Izu-Mariana-Yap island arc system. In Gass, I. G., Lippard, S. J., and Shelton, A. W. (Eds.), Ophiolites and Ocean Lithosphere (Vol. 13): Oxford (Blackwell), 291-302.

Okada, H., and Bukry, D., 1980. Supplementary modification and introduction of code numbers to the low-latitude coccolith biostratigraphic zonation (Bukry, 1973; 1975). Mar. Micropaleontol., 5:321-325.

Pearce, J. A., 1983. Role of the sub-continental lithosphere in magma genesis at active continental margins. In Hawkesworth, D. J., and Norry, M. J. (Eds.), Continental Basalts and Mantle Xenoliths: London (Shiva Publ.), 231-249.

Peccerillo, A., and Taylor, S. R., 1976. Geochemistry of Eocene calc-alkaline rocks from the Kastamonu area, Northern Turkey. Contrib. Mineral. Petrol., 58:63-81.

Poldervaart, A., and Hess, H. H., 1951. Pyroxenes in the crystallization of basaltic magma. J. Geol., 59:472-489.

Stern, R. J., Bloomer, S. H., Ping-Nan, L., and Smoot, N. C., 1989. Submarine arc volcanism in the southern Mariana arc as an ophiolite analogue. Tectonophysics, 168:151-170.

Sun, S. S., and McDonough, W. F., 1989. Chemical and isotopic systematics of oceanic basalts: implications for mantle composition and processes. In Saunders, A. D., and Norry, M. J. (Eds.), Magmatism in the Ocean Basins. Spec. Pap.-Geol. Soc. London, 42:313-345.

Uyeda, S., and Ben-Avraham, Z., 1972. Origin and development of the Philippine Sea. Nature Ph. Sci., 240:176-178.

Volpe, A. M., McDougall, J. D., and Hawkins, J. W., 1987. Mariana Trough basalts (MTB): trace element and $\mathrm{Sr}-\mathrm{Nd}$ evidence for mixing between MORB-like and arc-like melts. Earth Planet. Sci. Lett., 82:241-254.

Wood, D. A., Marsh, N. G., Tarney, J., Joron, L. J., Fryer, P., and Treuil, M., 1982. Geochemistry of igneous rocks recovered from a transect across the Mariana Trough, Arc, Fore-Arc, and Trench, Sites 453 through 461, Deep Sea Drilling Project Leg 60. In Hussong, D. M., and Uyeda, S., et al., Init. Repts. DSDP, 60: Washington (U.S. Govt. Printing Office), 611-645.

Woodhead, J. D., 1988. The origin of geochemical variations in Mariana lavas: a general model for petrogenesis of intraoceanic island arcs. J. Petrol., 29:805-830.

, 1989. Geochemistry of the Mariana arc (Western Pacific): source composition and processes. Chem. Geol., 76:1-24.

Date of initial receipt: 1 October 1990

Date of acceptance: 21 July 1991

Ms 125B-501 